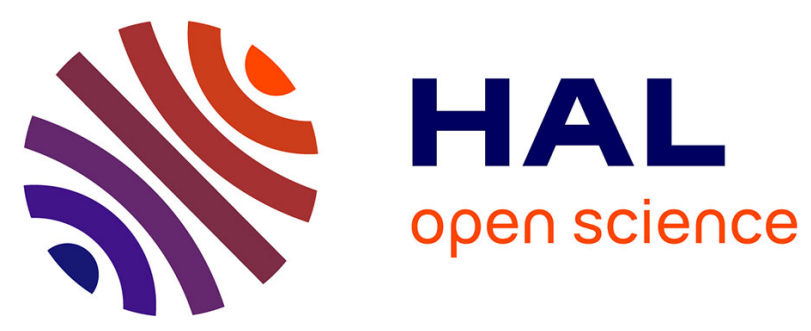

\title{
Interrelations between extensional shear zones and synkinematic intrusions: The example of Ikaria Island (NE Cyclades, Greece)
}

Valentin Laurent, Alexandre Beaudoin, Laurent Jolivet, Laurent Arbaret, Romain Augier, Aurélien Rabillard, Armel Menant

\section{To cite this version:}

Valentin Laurent, Alexandre Beaudoin, Laurent Jolivet, Laurent Arbaret, Romain Augier, et al.. Interrelations between extensional shear zones and synkinematic intrusions: The example of Ikaria Island (NE Cyclades, Greece). Tectonophysics, 2015, 651-652, pp.152-171. 10.1016/j.tecto.2015.03.020 . insu-01145425

\section{HAL Id: insu-01145425 \\ https://hal-insu.archives-ouvertes.fr/insu-01145425}

Submitted on 24 Apr 2015

HAL is a multi-disciplinary open access archive for the deposit and dissemination of scientific research documents, whether they are published or not. The documents may come from teaching and research institutions in France or abroad, or from public or private research centers.
L'archive ouverte pluridisciplinaire HAL, est destinée au dépôt et à la diffusion de documents scientifiques de niveau recherche, publiés ou non, émanant des établissements d'enseignement et de recherche français ou étrangers, des laboratoires publics ou privés. 


\title{
Interrelations between extensional shear zones and synkinematic intrusions: the example of Ikaria Island (NE Cyclades, Greece)
}

Valentin LAURENT, Alexandre BEAUDOIN, Laurent JOLIVET, Laurent ARBARET, Romain AUGIER, Aurélien RABILLARD, Armel MENANT

(1) Université d'Orléans, ISTO, UMR 7327, 45071, Orléans, France

(2) CNRS/INSU, ISTO, UMR 7327, 45071 Orléans, France

(3) BRGM, ISTO, UMR 7327, BP 36009, 45060 Orléans, France

(valentin.laurent@univ-orleans.fr, alexandre.beaudoin@univ-orleans.fr, laurent.jolivet@univorleans.fr, laurent.arbaret@univ-orleans.fr, romain.augier@univ-orleans.fr, aurelien.rabillard@univorleans.fr, armel.menant@cnrs-orleans.fr)

\begin{abstract}
The Aegean extensional backarc domain is an ideal place to investigate the interrelations between syntectonic intrusions and large-scale detachments, understanding whether the intrusions have a triggering effect on the inception of metamorphic core complex formation or not. A new field study of Ikaria Island (NE Cyclades, Greece) in two Miocene granitoid plutons intruding a high-temperature metamorphic dome, namely the Raches and Karkinagrion granites, leads to the identification of a major structure that has been omitted in previous studies: the Gialiskari Detachment. This regional-scale detachment is correlated with the North Cycladic Detachment System. Structural fieldwork at the scale of the entire Raches and Karkinagrion intrusions allows us to propose a map of strain intensity in these granites.
\end{abstract}


This map, based on macrostructural criteria, highlights a strong strain gradient in both intrusions from base to top, when approaching the Gialiskari Detachment. Along the strain gradient, a continuum of top-to-the north shearing deformation is recognized, including i) syn-magmatic deformation, ii) high-temperature ductile deformation at submagmatic state, iii) mylonitic to ultramylonitic deformation, iiii) low-temperature brittle deformation. A scenario of the interactions between the detachment and the Raches and Karkinagrion intrusions during their emplacement is proposed. We show that these granites were emplaced while the exhumation of the Ikaria metamorphic dome was already underway. We conclude that these plutons do not initially localize detachments, and instead that detachments localize and control the ascent of plutons. Intrusions then interact with detachments, accommodating their upward migration in the crust. This scenario is described on other Cycladic islands such as on Tinos or Mykonos. At a larger scale, the final emplacement of plutons may result from the flow of molten crust toward metamorphic core complex during extension.

\section{Keywords}

Backarc extension, metamorphic core complexes, detachment, intrusions, Aegean, Ikaria Island

\section{Highlights}

1) New geological and structural map of Ikaria Island (Cyclades, Greece)

2) Migmatites are closely associated with the Karkinagrion S-type granite

3) The Gialiskari Detachment is a regional-scale top-to-the north shear zone

4) Semi-quantitative characterization of a strain gradient in granitic plutons

5) Detachments localize and control the ascent of intrusions 


\section{1) Introduction}

Metamorphic Core Complexes (MCCs) are crustal-scale structures exhumed by major shallow-dipping extensional shear zones, or detachments. They result from the intense thinning of a previously thickened continental crust in post-orogenic extensional context (Dewey, 1988). First described in the Basin and Range Province (Davis and Coney, 1979; Crittenden et al., 1980; Wernicke, 1981) these structures were later recognized throughout the world in young mountain belts (e.g. Papua New Guinea, Baldwin et al., 1993; Lister and Baldwin, 1993; Himalayas, Aoya et al., 2005) or more ancient belts (French variscanides, Burg et al., 1994; Turrillot et al., 2011; Norwegian Caledonides, Andersen et al., 1991; Labrousse et al., 2002). MCCs development is often spatially and temporally associated with intense magmatic activity (Crittenden et al., 1980; Hill et al., 1992; Baldwin et al., 1993; Jolivet and Brun, 2010) and the development of detachments often interacts with syntectonic intrusions. On the one hand, detachments may either be seen as conduits for ascending magmas or as barriers limiting their rise (D'Lemos et al., 1992; Hutton and Reavy, 1992; Brown, 1994; Brown and Solar, 1998a). On the other hand, field studies and thermomechanical modeling have shown that shear zones can nucleate within partly crystallized plutons that introduce a local, yet drastic rheological heterogeneity in the crust (Lister and Baldwin, 1993; Neves et al., 1996; Forster et al., 2001; Aoya et al., 2005). Therefore, the role of detachments in the emplacement of magmatic intrusions, or conversely, the role of intrusions to localize deformation remains not clearly understood.

Series of MCCs have been described in the Mediterranean region, notably in the Aegean domain (Lister et al., 1984; Gautier et al., 1993; Jolivet et al., 2004), where some of the Cycladic islands (e.g. Mykonos, Naxos, Ios, Tinos, Serifos, Andros and Paros) expose the relations between MCCs and intrusions (Lister et al., 1984; Faure and Bonneau, 1988; Avigad and Garfunkel, 1989; Urai et al., 1991; Buick, 1991a; Gautier et al., 1993; Gautier and Brun, 
1994; Lee and Lister, 1992; Vandenberg and Lister, 1996; Grasemann and Petrakakis, 2007; Denèle et al., 2011; Rabillard et al., submitted). Indeed, these MCCs, characterized by series of ductile-then-brittle detachment systems, are often intruded by syntectonic Miocene plutons (Lister and Baldwin, 1993; Jolivet et al., 1994; 2010; Lecomte et al., 2010; Rabillard et al., submitted). These detachment systems comprise the North Cycladic Detachment System (NCDS), the West Cycladic Detachment System (WCDS) and the Paros-Naxos Detachment and have accommodated the exhumation of these MCCs (Jolivet et al., 2010; Grasemann et al., 2012).

The geometrical and kinematic relations between plutons and detachments have been described on Naxos and Mykonos with quite some details (Andriessen et al., 1979; Keay et al., 2001; Urai et al., 1991; Buick, 1991a; Gautier et al., 1993; Lecomte et al., 2010; Denèle et al., 2011) but the largest Cycladic pluton (Raches pluton on Ikaria Island) has so far not been studied in detail. In this paper, we study the geometrical kinematic setting of the emplacement of intrusions on Ikaria Island and their evolution through time. Combining these data with recent studies of the metamorphic part of the island, we discuss the large-scale interrelations between the extensional structures, the Ikaria MCC and the synkinematic intrusions, from the scale of the island up to the Aegean domain.

\section{2) Geological setting}

\section{1) Tectonic evolution of the Cycladic Archipelago}

Located in the eastern part of the Mediterranean area, the Aegean domain (Fig. 1a) corresponds to a collapsed segment of the Hellenic belt above a north-plunging subduction (Le Pichon and Angelier, 1979; Le Pichon, 1982; Jolivet et al., 1994; Gautier et al., 1999; 
Jolivet and Faccenna, 2000). The Aegean domain underwent a complex Alpine history that can be summarized in two main successive steps: 1) the late Cretaceous-Eocene formation of the Hellenides-Taurides belt resulted from the convergence between Africa and Eurasia plates. During this episode, a series of oceanic and continental nappes entered the subduction zone and were thrust on top of each other in a high-pressure and low-temperature (HP-LT) metamorphic context (Bonneau and Kienast, 1982), 2) The inception and acceleration of African slab retreat from 30-35 Ma led to the crustal collapse in the backarc domain, the dislocation of the nappe stack and the formation of MCCs (Le Pichon and Angelier, 1981; Lister et al., 1984; Jolivet et al., 2004a; 2013). North-south (N-S) extension in the backarc domain was characterized by a distributed deformation over a wide region covering the entire Aegean Sea, part of western Anatolia and the Rhodope massif in the north. The extensional tectonic regime was also characterized by more localized deformation with the development of MCCs where the exhumation of HP-LT units was completed in a low-pressure and hightemperature (LP-HT) environment (Fig. 1a; Jolivet and Patriat, 1999). 


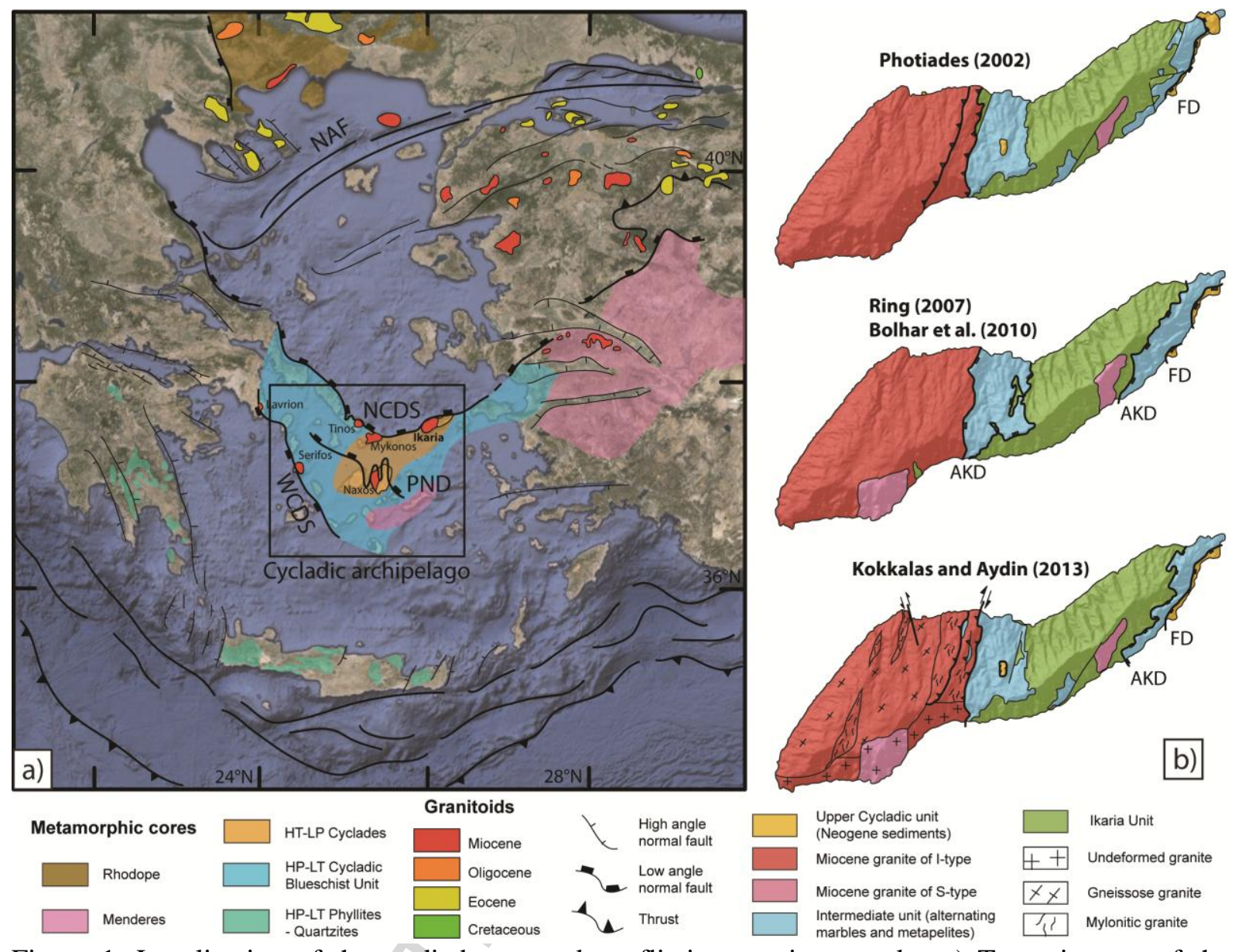

Figure 1: Localization of the studied area and conflicting previous works. a) Tectonic map of the Aegean domain showing the distribution of metamorphic cores and granitoids and their link with major tectonic structures such as the North Cycladic Detachment System (NCDS), the West Cycladic Detachment System (WCDS), the Paros-Naxos Detachment (PND) and the North Anatolian Fault (NAF), modified after Jolivet et al. (submitted). b) Representation of the different author interpretations of the structures composing the island of Ikaria, especially on the ambiguous nature of the contact between the granite and the metamorphic dome and on the geometry of major tectonic contact such as the Fanari Detachment (FD) and the Agios Kirykos Detachment (AKD).

The Cycladic archipelago is located in the center of the Aegean domain and corresponds to the deepest exhumed parts of the Hellenides-Taurides belt (Fig. 1a). Three tectonic units are traditionally recognized in the Cyclades (Bonneau, 1984; Jolivet et al., 2004b), 1) The Upper Cycladic unit (UC) corresponds to the shallowest part of the nappe stack. It is composed of non-metamorphic Permian to Mesozoic sediments, some minor, mainly Cretaceous, orthogneisses, ophiolites and rocks metamorphosed under greenschistfacies to amphibolite-facies conditions, 2) The Cycladic BlueSchist unit (CBS) is structurally positioned below the UC unit. It is composed of metapelites, quartzites, marbles and various 
amounts of metabasites all equilibrated in blueschist- or eclogite-facies conditions (e.g. Blake et al., 1981; Bonneau, 1984; Avigad and Garfunkel, 1991). The CBS unit experienced a complex Alpine tectonometamorphic evolution, with an early burial in HP-LT conditions reaching $\sim 18-20 \mathrm{kbar}$ and $500-550^{\circ} \mathrm{C}$ (Dürr et al., 1978; Bröcker and Enders, 2001; Trotet et al., 2001; Parra et al., 2002; Tomaschek et al., 2003; Augier et al., 2015) during the Eocene, followed by a greenschist to amphibolite overprint of variable intensity during the Oligocene and the Miocene (Altherr et al., 1979, 1982; Wijbrans and McDougall, 1986; Buick, 1991; Keay et al., 2001; Duchêne et al., 2006), 3) The Cycladic Continental Basement (CCB) crops out on different islands from the center to the south of the Cyclades (e.g. Paros, Naxos, Ios or Sikinos) and is structurally positioned beneath the CBS (e.g. Andriessen et al., 1987; Huet et al., 2009). This unit is composed of Variscan orthogneisses mantled by metasediments that locally retain metamorphic relics of amphibolite-facies assemblages suggesting a complex pre-Alpine history (e.g. Bonneau and Kienast, 1982; Andriessen et al., 1987; Keay, 1998; Photiades and Keay, 2003). Late exhumation stages of both the CBS and the CCB were accompanied by the emplacement of syntectonic Miocene intrusions (Fig. 1a; e.g. Tinos, Mykonos, Ikaria, Naxos, Serifos or even Lavrion; Jansen, 1973; Altherr et al., 1982; Faure et al., 1991; Lee and Lister, 1992; Altherr and Siebel, 2002; Pe-Piper et al., 2002; Grasemann and Petrakakis, 2007; Iglseder et al., 2009; Bolhar et al., 2010; Lecomte et al., 2010; Stouraiti et al., 2010; Denèle et al., 2011). These intrusions are of two types: 1) S-type per-aluminous two-mica leucogranites and granites and 2) I-type granites resulting from lower crust and mantle partial melting (Altherr and Siebel, 2002; Pe-Piper et al., 2002). In the entire Aegean domain, magmatic intrusions were all dated between 15 and $10 \mathrm{Ma}$ while volcanic rocks yielded ages between 11 and 6 Ma (Altherr et al., 1982; Fytikas et al., 1984; Weidmann et al., 1984; Keay, 1998; 2001; Brichau et al., 2007; Liati et al., 2009; Baltatzis et al., 2009; Bolhar et al., 2010). The southward younging emplacement ages of both volcanic and magmatic 
rocks highlight the southward migration of the magmatic arc in relation to the retreating African slab (Fig. 1a).

\section{2) Geology of Ikaria}

Ikaria Island is located in the northeastern part of the Cyclades, near the west coast of Turkey and close to the island of Samos. Three tectonic units are recognized (Fig. 1b; Papanikolaou, 1978; Altherr et al., 1982; Photiades, 2002; Kumerics et al., 2005; Beaudoin et al., submitted), from top to bottom:

1) The non-metamorphic Fanari unit, correlated with the UC unit corresponds to series of Miocene to Pliocene sandstones, conglomerates and ophiolitic molasses (Photiades, 2002).

2) The intermediate unit consists of alternating marble and metapelite layers, metamorphosed in greenschist-facies conditions (Altherr et al., 1982; Kumerics et al., 2005; Beaudoin et al., submitted). Recently, based on structural and metamorphic criteria, Beaudoin et al. (submitted) have reinterpreted the geometry of this unit, called Messaria unit by Kumerics et al. (2005), and renamed it as the Agios Kirykos unit. This term is then used hereafter in this study.

3) The Ikaria unit is composed of an up to $1 \mathrm{~km}$-thick association of metasediments including micaschist and marble layers and minor metabasite occurrences (Photiades, 2002). Rocks of this unit were equilibrated in amphibolite-facies conditions (i.e. Altherr et al., 1982; Kumerics et al., 2005; Martin et al., 2011) at ca. 6-8 kbar and 600-650 ${ }^{\circ} \mathrm{C}$. Peak-metamorphic conditions were retrieved from the basal parts of the succession (Martin, 2004; Kumerics et al., 2005; Martin et al., 2011; Beaudoin et al., submitted).

Recent studies in the metamorphic dome (Ring, 2007; Kumerics et al., 2005; Beaudoin et al., submitted) show the presence of two low-angle ductile shear zones on Ikaria: 1) the Fanari Detachment cropping out in the northeastern part of the island shows a continuum of 
deformation from ductile to brittle conditions. This detachment is located at the contact between the Agios Kirykos and Fanari (UC) units, except for its northern part where it juxtaposes directly the Fanari and Ikaria units (Fig. 2), 2) The second low-angle ductile shear zone corresponds to the Agios Kirykos Detachment. This detachment is located between the Ikaria high-temperature metamorphic unit and the Agios Kirykos lower temperature metamorphic unit (Beaudoin et al., submitted). Conversely to the Fanari Detachment, this detachment became inactive in the ductile regime and does not show any brittle deformation imprint.

Three main granitic intrusions are recognized on Ikaria Island (Fig. 2; Ring, 2007; Bolhar et al., 2010; Kokkalas and Aydin, 2013): two small-scale S-type intrusions (Xylosyrtis and Karkinagrion) and the large I-type Raches intrusion that constitutes the largest magmatic intrusion of the whole Cycladic archipelago (Altherr et al., 1982; Photiades, 2002; Kumerics et al., 2005).

The S-type Xylosyrtis granite intrudes the Ikaria unit on the southeastern coast of the island. The intrusion consists of a two-mica granite with an uniformly fine grain-size and characterized by a mineral assemblage of feldspar, plagioclase, quartz, biotite and muscovite. Minor and accessory phases are green hornblende, apatite, zircon, tourmaline, magnetite and cassiterite (Altherr et al., 1982; Photiades, 2002). Emplacement of this granitic pluton was dated by $\mathrm{U} / \mathrm{Pb}$ method in zircon at $14.63 \pm 0.67 \mathrm{Ma}$ (Bolhar et al., 2010).

The Raches granite composes the western part of the island. This I-type granite of calc-alkaline composition belongs to the Miocene magmatic arc of potassic plutons parallel to the Hellenic Trench (Altherr et al., 1982). Mineral assemblage consists of feldspar phenocrysts, zoned plagioclase, quartz, biotite and hornblende with accessory phases such as red allanite, apatite, sphene, titanomagnetite, zircon, tourmaline or garnet (Altherr et al., 
1982). The emplacement of this granite was dated by $\mathrm{U} / \mathrm{Pb}$ method in zircon at $13.33 \pm 0.17$ Ma (Bolhar et al., 2010).

Due to its recent discovery (Ring, 2007), the S-type Karkinagrion granite has been little studied. Two statistically distinct ages were retrieved by the $\mathrm{U} / \mathrm{Pb}$ method in zircon at $13.73 \pm 0.29 \mathrm{Ma}$ and $16.67 \pm 0.64 \mathrm{Ma}$. Although the youngest age is slightly older than the one obtained for the emplacement of the Raches granite and without obvious evidence, Bolhar et al. (2010) concluded that the Karkinagrion granite intruded the I-type Raches granite.

At variance with the Xylosyrtis intrusion that displays a clear intrusive character within metamorphic series, the nature of the Raches granite contact with the metamorphic dome remains highly controversial. This contact was mapped so far as intrusive (Papanikolaou, 1978), as a detachment (Kumerics et al., 2005) or as a thrust (Fig. 1b; Boronkay and Doutsos (1994); Photiades, 2002; Kokkalas \& Aydin, 2013).

Deformation in intrusions remains poorly studied. Faure et al. (1991) described for the first time a widespread mylonitic foliation, a N-S stretching lineation and a preferred top-tothe north sense of shear in the Raches granite. These authors stated that magmatic deformation is seldom preserved on Ikaria and only mylonitic, subsolidus deformation is currently observable. Besides, Kokkalas and Aydin (2013) elaborated a deformation map of the Raches granite and concluded that the strain increases from west to east when approaching the contact between the granite and metamorphic units, described as a large thrust with an oblique dextral motion (Fig. 1b).

It appears that the structure of the intrusive granitic bodies and their relation with the metamorphic host rock of Ikaria Island still remain poorly understood. However, this is crucial to address the feedback relationships between intrusions, detachments and the formation of MCC. In order to study these interrelations, we have reconsidered these discrepancies. An extensive field study on Ikaria Island was performed, including primarily 
new geological mapping of the geometry of the Raches and Karkinagrion plutons combined with a detailed study of the strain intensity affecting these intrusions. The detailed structural study shows contrasting results with respect to previously published papers. Main changes and their implications are shown below.

\section{3) Methods}

In order to start from a clear geometrical context the whole island has been remapped based on field observations and satellite images. The finite strain pattern has been studied and the result is given as maps of the foliation and stretching lineations in the metamorphic dome and in the intrusions. Kinematic indicators has been similarly systematically observed all over the island and reported on the map of stretching lineations. In order to obtain an image of the strain gradients within the intrusions a scale of strain intensity with seven grades, adapted to the Raches granite, was constructed and the deformation grade systematically reported on the map. Aiming at quantifying the strain intensity affecting the intrusions in more details, eight samples were selected all around the Raches granite in order to reconstruct the strain ellipsoid by image analysis, based on the shape fabric of biotite aggregates. Biotite was selected as strain indicator because it is easy to segment on images due to its strong color contrast with the felsic background. The protocol, similar to Launeau and Robin (2005), was first to cut rock samples along three orthogonal sections, one section in the XY plane of the finite strain ellipsoid parallel to foliation and lineation, one $\mathrm{YZ}$ section perpendicular to the lineation and one $\mathrm{XZ}$ section perpendicular to the foliation and parallel to the lineation. Then, 2D images of the three sections $\mathrm{XY}, \mathrm{XZ}$ and $\mathrm{YZ}$ of each sample were treated. This step was performed using GIMP 2 software and consisted of image enhancement (filters) and segmentation of the biotite phase. Filters and segmentation were adapted for each sample. Segmented images were then analyzed with the 2003 Intercept software (Launeau and Robin, 2005; Launeau et al., 
2010). Analyses were conducted with the intercept method that allows finding the preferential direction of biotite. This direction corresponds to the minimum number of intercepts (contact between the analyzed phase and the matrix). Finally, the 3D fabric ellipsoid was calculated by using the $2 \mathrm{D}$ analyses performed on the three orthogonal faces of our sample (Launeau et al., 2010).

Moreover, in this work chemical analyses of hornblende crystals have been performed in order to determine the pressure emplacement of the Raches intrusion using the experimental calibration of Schmidt (1992): $\mathrm{P}( \pm 0.6 \mathrm{~kb})=-3.01+4.76 \mathrm{Al}$ Tot. A Cameca SX50 electron probe microanalyzer at the University "Pierre et Marie Curie" (Paris VI) was used to acquire spot analyses of hornblendes. Analytical conditions for spot analyses were $15 \mathrm{kV}$ accelerating voltage and $10 \mathrm{nA}$ beam current. Standards used were $\mathrm{Fe}_{2} \mathrm{O}_{3}(\mathrm{Fe}), \mathrm{MnTiO}_{3}$ (Mn, Ti), diopside (Mg, Si), $\mathrm{CaF}_{2}(\mathrm{~F})$, orthoclase (Al, K), anorthite (Ca), albite (Na), and vanadinite $(\mathrm{Cl})$. The counting time was $10 \mathrm{~s}$ for all elements.

\section{4) Field observations}

\section{1) Nature of contact zones with intrusions}

A new field study of Ikaria Island was conducted and resulted in the proposition of a new geological map (Fig. 2, see also Beaudoin et al., submitted). Our survey shows that the Karkinagrion two-mica intrusion occupies a much larger volume than initially proposed by Bolhar et al. (2010) and we highlight for the first time the presence of migmatites closely associated to this S-type granite (Fig. 2). In this section, we explore and describe the different contact zones between the western set of intrusions and the wall rocks forming the Ikaria MCC. 


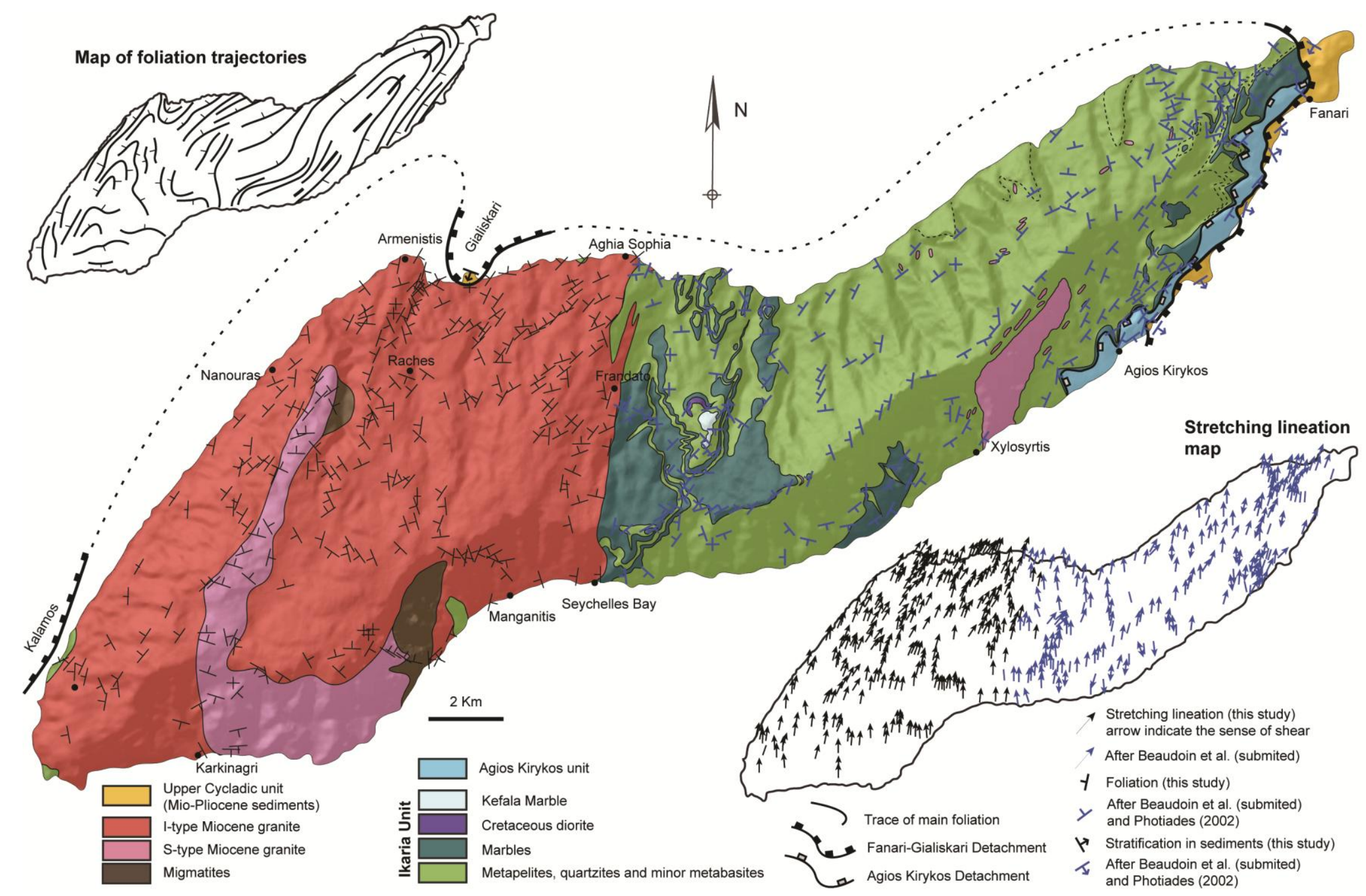

Figure 2: New geological map of Ikaria Island showing the tectonic units, the two Gialiskari and Agios Kirykos detachments, foliation trajectories, stretching lineation measurements and localities cited in the text. 


\subsection{1) Contact between the Raches intrusion and the Ikaria MCC}

The contact between the Raches intrusion and the Ikaria MCC is often hidden on land but is spectacularly exposed on the coast. The contact is described along strike from south to north.

The intrusive nature of the contact between the Raches granite and the metamorphic dome is well exposed along the southern coast of Ikaria near Seychelles Beach (Fig. 3a). Folded synplutonic dikes cutting the vertical foliation of the marble are observed. Two distinctive foliations, within the granite and the metamorphic dome, show a clear intrusive relation between these units. The marble unit appears strongly deformed with vertical foliation planes, while granitic dikes show only a weak folded foliation showing that the metamorphic rocks were already deformed when the intrusion emplaced. Thereby, the southern part of the contact is intrusive and rocks near this southern contact have been poorly deformed after the emplacement of the intrusion. 

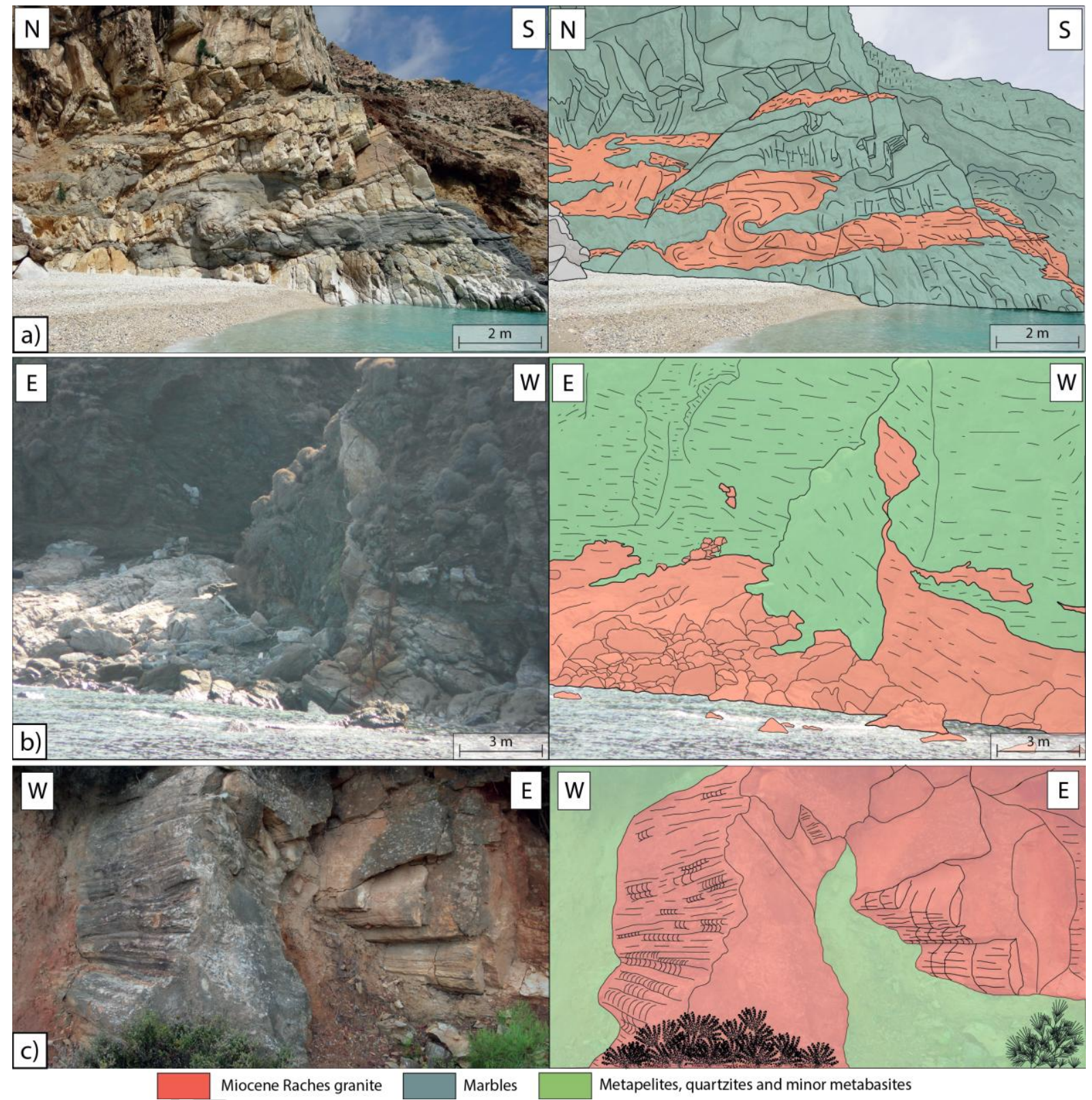

Figure 3: Photographs showing the intrusive nature of the contact between the Raches granite and metamorphic rocks. a) Southern part of the contact, where poorly deformed granitic dikes intruded highly deformed metamorphic units. b and c) Northern part of the contact, where granitic dikes intruded metamorphic host rocks. Rocks of both sides of this contact have been deformed as a single unit after the emplacement of the Raches granite.

In the northern part of the contact, near Aghia Sophia chapel (see location on Fig. 2), the intrusive nature of the contact is clearly observed at large scale in the landscape: near Frandato village, a several hundred meters-long branch of the granite intrudes the metamorphic unit (Fig. 2). Moreover, on the northern coast, granitic dikes intrude the host rocks (Fig. 3b). At the scale of the island, the contact is almost vertical and it undulates at 
small scale due to folding, as observed near Frandato village (Fig. 2), where other granitic dikes penetrate the host metamorphic rocks (Fig. 3c). The contact between these dikes and the host rock appears folded with N-S axes, parallel to the regional stretching lineation, and with horizontal axial planes. Rocks on both sides of this contact appear strongly deformed, with both granitic and metamorphic foliation planes being transposed at the contact. The northern contact geometry thus shows a clear intrusive relation and not the tectonic contact described by Boronkay and Doutsos (1994), Photiades (2002), Kumerics et al. (2005), Ring (2007) or Kokkalas and Aydin (2013). Rocks on either side of the northern part of the contact have been afterward deformed as a single unit. In contrast to the southern part of the contact, it is not possible to determine whether the metamorphic unit was already deformed before the emplacement of the Raches granite.

\subsection{2) Contact between the Raches and Karkinagrion intrusions}

Thanks to good outcrop conditions at the top of the reliefs (Fig. 4a), the contact between Raches and Karkinagrion intrusions can be studied near Raches village (see location on Fig. 2). There, the Karkinagrion granite occurs structurally above the Raches granite (Fig. 4b). At the contact, mylonitic foliation planes in both granites are parallel. Our new mapping reveals a much larger volume of the Karkinagrion granite than previously described by Ring (2007) and Bolhar et al. (2010; Figs. 1 and 2). We also report the presence of large-scale migmatite massifs near Manganitis and Raches, found at the contact with the Karkinagrion granite (Figs. 2 and 4c). A gradual transition from migmatites to this two-mica granite is observed, implying that the granite is closely associated and then coeval with migmatites. Therefore, the emplacement scenario first proposed by Bolhar et al. (2010) must be redefined. It is here concluded that the Raches granite intruded the lower parts of the Ikaria MCC made 
of migmatites and in-situ granites such as the Karkinagrion intrusion. These observations are

furthermore in agreement with available radiometric ages (Bolhar et al., 2010).

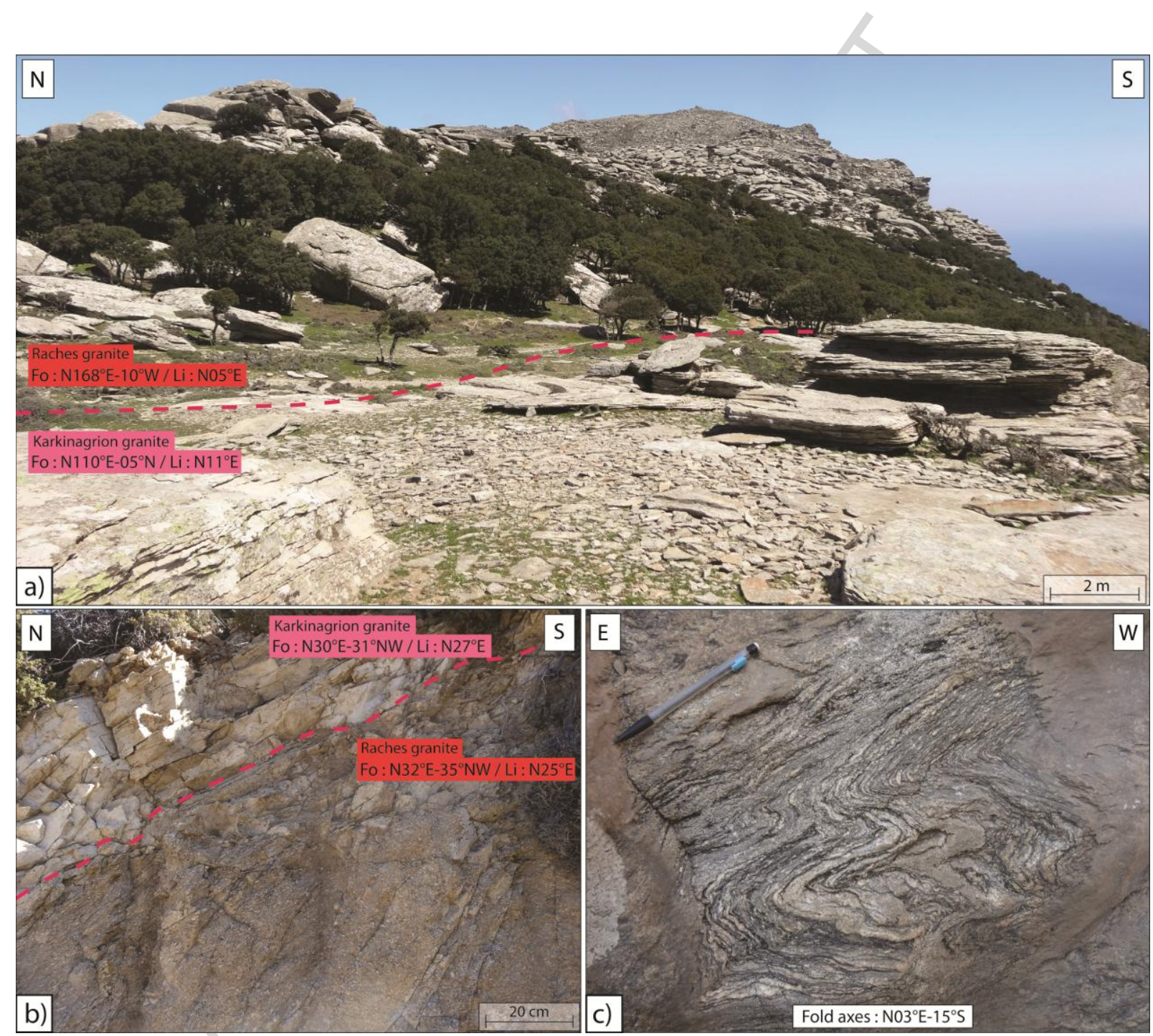

Figure 4: Photographs showing the contact between the Raches and Karkinagrion granites. a) Largescale field view of this contact. b) At the contact, these two granites have parallel foliation (Fo) and lineation (Li). c) Migmatites were found in close contact with the Karkinagrion granite, with a progressive transition from S-type granitic to migmatitic composition. 


\subsection{3) Contact between the Raches granite and a Mio-Pliocene sedimentary unit}

As observed in the NE part of the island, the Pliocene sedimentary unit, regionally correlated with the UC unit, occurs in the northern part of the Raches intrusion near the village of Gialiskari (Fig. 5a). Here, this unit is made of Miocene sandstones and conglomerates fed by the Pelagonian unit. As observed in the metamorphic dome near Fanari (Beaudoin et al., submitted), this unit is separated from the underlying Raches intrusion by a major tectonic contact (Fig. 2). Despite its importance, this contact has been omitted in recent studies (Kumerics et al., 2005; Ring, 2007; Bolhar et al, 2010; Kokkalas and Aydin, 2013) and remains currently not described in detail. The contact zone between the granite and the sedimentary unit is marked by a shallow-dipping $\left(10-15^{\circ}\right)$ mylonitic foliation carrying a $\mathrm{N} 30^{\circ}$ E stretching lineation (Figs. 2 and 5b). A widespread S-C fabric points to a clear top-tothe north sense of shear (Fig. 2). In addition, the contact itself is marked by a thick cataclastic band reaching ca. $10 \mathrm{~m}$ in thickness that partially reworks the mylonites and ultramylonites (Fig. 5c). Conversely, the Mio-Pliocene sedimentary unit is affected only by two conjugate sets of north- and south-dipping brittle normal faults with N-S to NE-SW oriented displacements, consistent with the ductile stretching direction in the granite (Fig. 5d). 

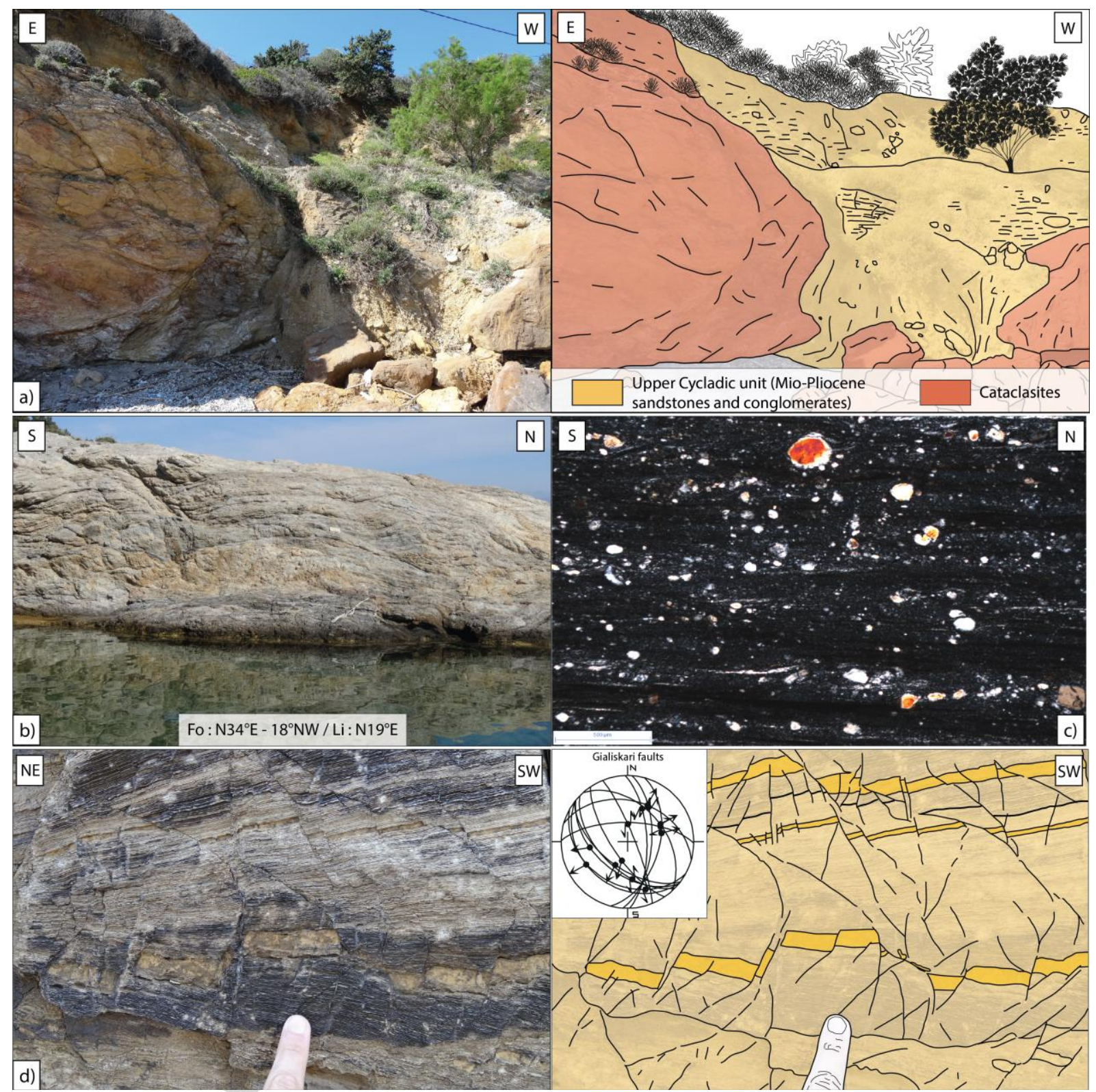

Figure 5: Photographs showing the contact between the Raches intrusion and a Mio-Pliocene sedimentary unit. This major tectonic contact superposed a non-metamorphic sedimentary unit above the Raches granite. At the contact, the Raches granite is strongly deformed: a) ten meters of cataclasites, b) mylonites associated to a stretching lineation oriented $\mathrm{N} 10^{\circ} \mathrm{E}$ to $\mathrm{N} 30^{\circ} \mathrm{E}, \mathrm{c}$ ) Microphotography illustrating the grain size reduction associated with ultramylonites. d) The nonmetamorphic sedimentary unit revealed only brittle deformation plotted on a stereogram.

\section{2) Recognition of four deformation styles $\left(D_{1}\right.$ to $\left.D_{4}\right)$}

In order to investigate the interrelations between intrusions and the Ikaria MCC, an extensive field survey including structural observations on 266 sites was performed over the Raches and Karkinagrion granites. These intrusions recorded, at least locally, a strong ductile 
and then brittle deformation as attested by the presence of ultramylonites and cataclasites (Fig. 5). The most obvious feature of our field study is that the whole Raches and Karkinagrion intrusions are affected by a top-to-the north asymmetric deformation, consistent with our observations near Gialiskari (Fig. 2). Moreover, intrusions show evidence for four distinct deformation structures $\left(D_{1}\right.$ to $\left.D_{4}\right)$ that probably occurred during a single continuum of top-to-the north shearing deformation, i.e. the same progressive tectonic event through strain localization.

The first deformation feature $\left(D_{1}\right)$, is recorded in the poorly deformed rocks of intrusions and is characterized by homogeneous sub-horizontal mineral lineation oriented N-S and a sub-vertical foliation (Fig. 6a). Feldspar phenocrysts are all aligned but not internally deformed (Fig. 6b). These crystals had to be free to rotate within the magma when they became oriented. D1 can thus be considered as a magmatic fabric. 

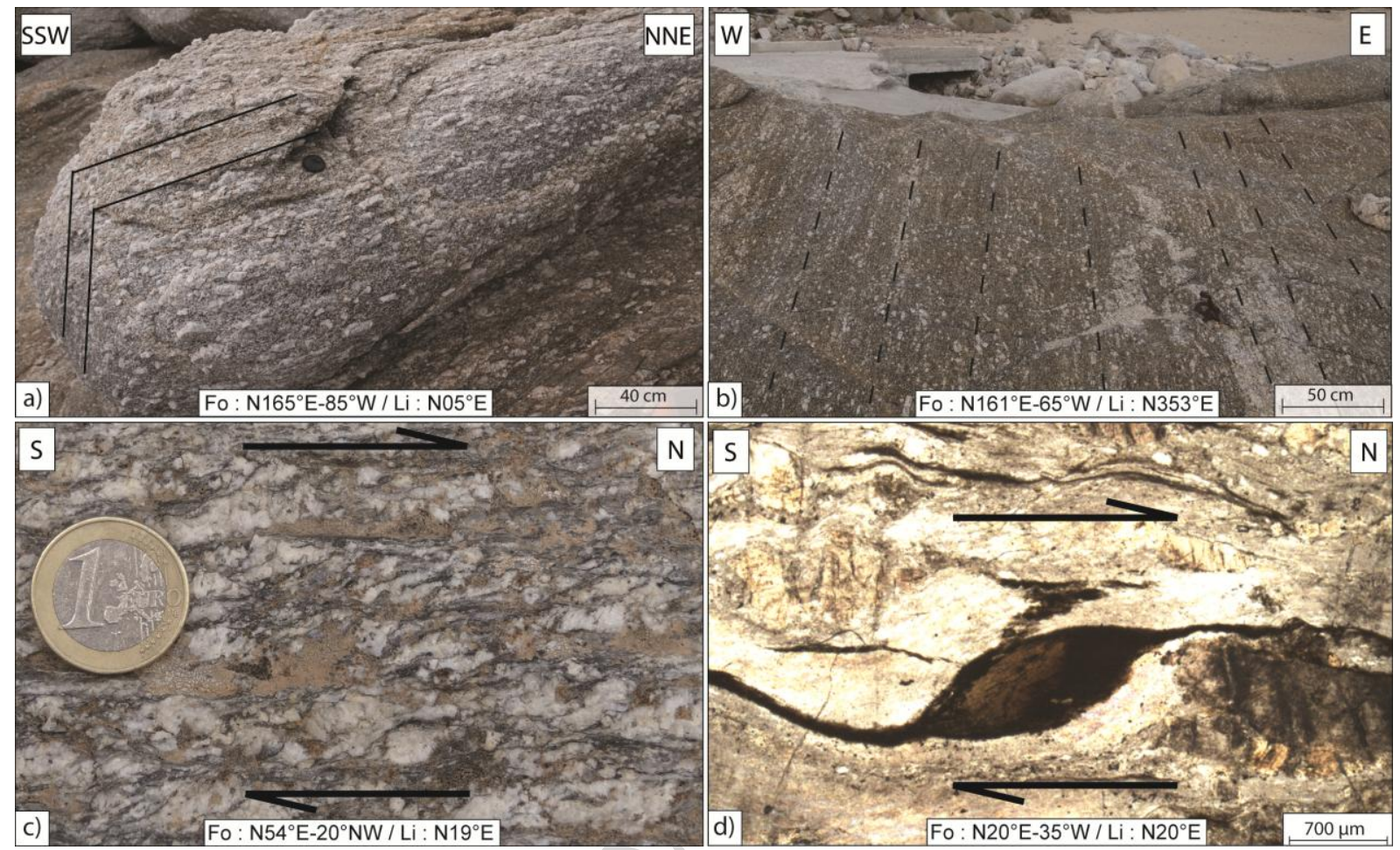

Figure 6: Photographs showing field evidence of an unequal distribution of ductile deformation in the intrusive. a) and b) Poorly deformed Raches granite with preserved vertical foliation and north-south mineral lineation characterizing the $\mathrm{D}_{1}$ deformation structure. c) and d) All kinematic indicators in mylonites, such as S-C shear bands or sigmoidal biotite, show top-to-the north sense of shear. These mylonites, characteristic of the $\mathrm{D}_{3}$ deformation feature, are characterized by a low dipping foliation and a stretching lineation oriented $\mathrm{N} 10^{\circ} \mathrm{E}$ to $\mathrm{N} 30^{\circ} \mathrm{E}$.

On incipiently deformed rocks, microfractures are observed in potassium feldspar, reflecting the $\mathrm{D}_{2}$ set of structures (Fig. 7). Bouchez et al. (1992) describe three conditions to consider microfractures in feldspar as indicating submagmatic state deformation: 1) microfractures should not intersect more than one grain to ensure that each crystal has been in contact with the magma, 2) Mineral phases filling microfractures should have the same magmatic composition and should be in crystallographic continuity with mineral phases outside the fracture. In these samples, the two conditions were met (Fig. 7) and $\mathrm{D}_{2}$ can thus be considered as a submagmatic state deformation. 


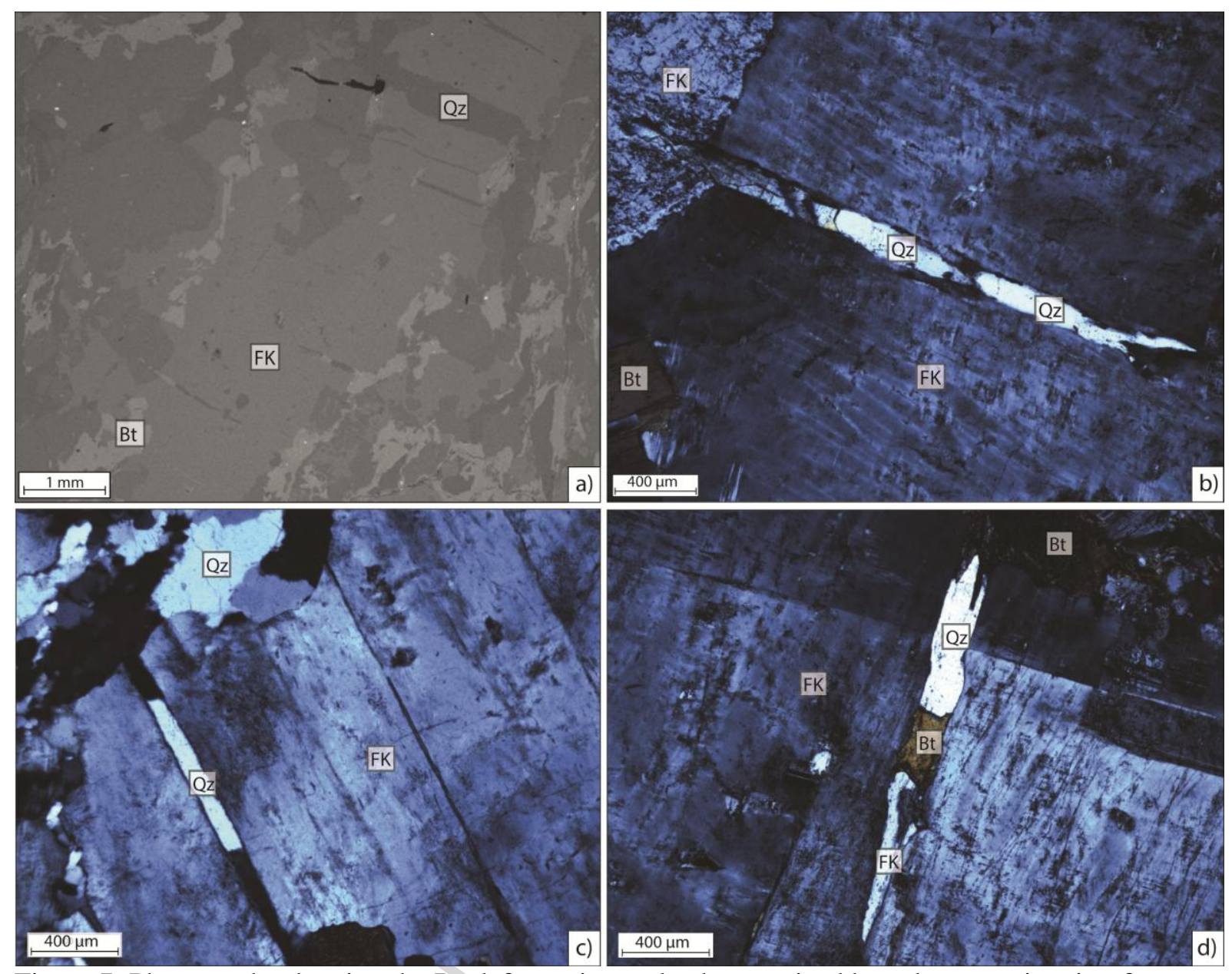

Figure 7: Photographs showing the $\mathrm{D}_{2}$ deformation style characterized by submagmatic microfractures in potassic feldspar (FK), a) Back scattered Scanning Electron Microscope (SEM) micrograph showing several microfractures in a single FK crystal. b) and c) Mineral phases filling the microfractures are in crystallographic continuity with mineral phases outside the fracture and not deformed. d) Microfracture with a coherent magmatic composition of FK + biotite (Bt) + Quartz (Qz).

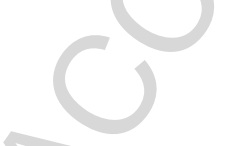

The third set of structures $\left(\mathrm{D}_{3}\right)$ is characterized by a less steep foliation $\left(15-30^{\circ}\right)$ and a stretching lineation oriented $\mathrm{N} 10^{\circ} \mathrm{E}$ to $\mathrm{N} 30^{\circ} \mathrm{E}$. All kinematic indicators show a top-to-the northeast ductile shear sense (Figs. 2 and $6 c, d$ ). $D_{3}$ is characterized by unevenly distributed proto-mylonitic, mylonitic and ultramylonitic facies. The grain size of crystals, and especially feldspar phenocrysts, is reduced with the increase of strain (Figs. 5c and 6c).

While deformation styles $\mathrm{D}_{1}, \mathrm{D}_{2}$ and $\mathrm{D}_{3}$ qualified a magmatic, submagmatic or ductile deformation, the $\mathrm{D}_{4}$ deformation features are characterized by pure brittle deformation recorded throughout the granite. North-dipping low-angle normal fault planes are observed with striations parallel to the stretching lineation in mylonites (Fig 8a). Moreover, normal 
steeply dipping brittle faults oriented E-W are observed consistently with a N-S extension (Fig. 8b).
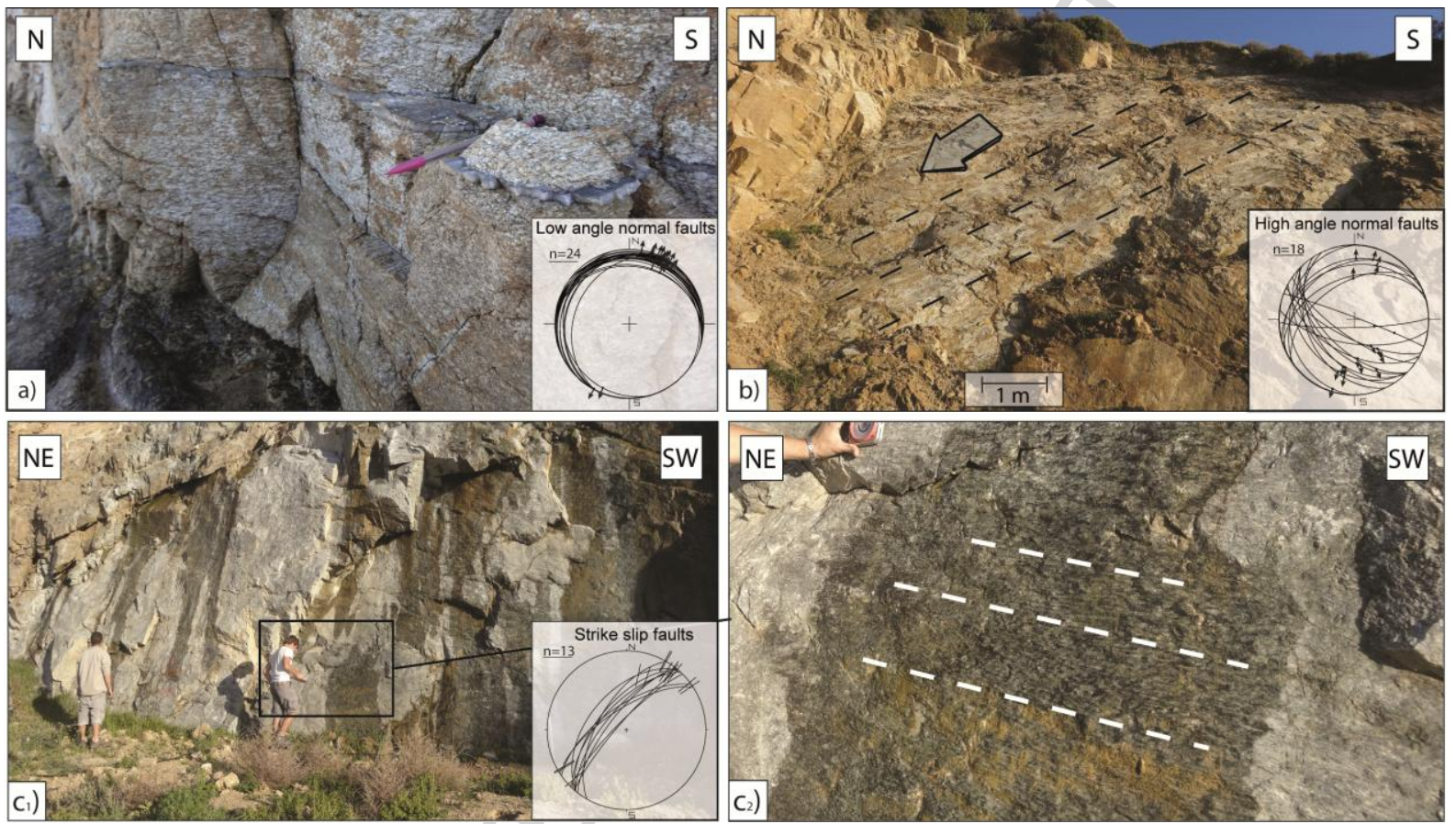

Figure 8: Photographs showing the brittle $\mathrm{D}_{4}$ style of deformation in the Raches granite. This deformation was characterized by both low-angle (a) and steeply dipping (b) normal faults. In addition to normal faults, the brittle deformation was marked by large strike-slip fault planes with ambiguously sense motion not taken in consideration (c).

Near the village of Nanouras, some striated planes have been observed. These planes have a consistent NE-SW orientation with sub-horizontal striations (Fig. 8c). The lack of kinematic indicators on fault planes does not allow firmly concluding on the motion sense. Thus, relationships between these structures and the regional top-to-the north ductile shearing remain unclear.

Structurally just below the northern contact between the Raches granite and the Gialiskari sedimentary unit, about 10 m-thick cataclasites are observed. Cataclasites are also found on the southwest coast, near the village of Kalamos. These cataclasites represent the last brittle increment of the deformation. 


\section{3) Distribution of the magmatic and ductile deformation $\left(D_{1}, D_{2}\right.$ and $\left.D_{3}\right)$}

\subsection{1) Field mapping of deformation intensity}

Our study of the deformation has shown that in the whole Raches and Karkinagrion intrusions, the ductile deformation is geometrically unevenly distributed. Indeed, these intrusions show a distinct shallow-dipping foliation carrying a $\mathrm{N} 10^{\circ} \mathrm{E}$ to $\mathrm{N} 30^{\circ} \mathrm{E}$ trending stretching lineation above a core of less deformed granite characterized by a subvertical foliation and a N-S lineation (Figs. 2 and 6). Moreover, all kinematic indicators in tectonically deformed rocks such as S-C fabric, rotated porphyroclasts and sigmoidal foliation, show topto-the north sense of shear, suggesting the presence of a thick north-dipping mylonitic shear zone deforming the upper part of granites, especially the Raches granite near the northern contact with the upper sedimentary unit at Gialiskari. Open folds furthermore deform the foliation with axes parallel to the stretching lineation. Because of shallow dip toward the north of these late fold axes, a south to north transect crosses the strain gradient upward, i.e. toward the most deformed structural part of the granite. In order to characterize the distribution of this ductile deformation, the intensity of finite deformation was mapped at high resolution. The strain gradient that affected the orthogneisses, resulting from the deformation of the same granitic protoliths, was characterized by defining seven strain facies of ductilely deformed granites as proposed by Huet et al. (2009) or Charles et al. (2010; Fig. 9). Each grade of deformation was defined on macro-structural criteria adapted to fieldwork, such as the shape and size of the main minerals but also the succession of microstructures developing during progressive deformation. The seven strain facies were defined as follows:

Grade 0 corresponds to an isotropic magmatic fabric. The term "magmatic fabric" is used in the mechanical sense, so when there is no direct interaction (contact) in the magma between 
phenocrysts (Vernon, 2000) and no magmatic preferred orientation develops. The granite shows neither foliation nor lineation and minerals are not deformed (Fig. 9a).

Grade 1 corresponds to an anisotropic magmatic fabric. Minerals are not deformed but an incipient foliation and/or lineation can be observed (Fig. 9b).

Grade 2 can no longer be considered as a pure magmatic fabric. Feldspar megacrysts start to be deformed, which suggests interactions between phenocrysts in the magma. Some FK are not deformed while others are stretched, boudinaged and sheared (Fig. 9c). Elongated clusters of biotite mark the stretching lineation.

Grade 3 is marked by the appearance of a weak foliation, a clear stretching lineation, a few penetrative shear bands that affect large volume of rocks, grain-size reduction and clear quartz ribbons (Fig. 9d). This fabric can be qualified as protomylonitic.

Grade 4 is characterized by a strong foliation and lineation with increasing number of shear bands associated with stretched biotite and quartz ribbons (Fig. 9e). This fabric can be qualified as mylonitic.

Grade 5 shows the presence of ultramylonite bands in addition to the mylonitic shear bands of grade 4 (Fig. 9f). The average thickness of these bands varies from a few centimeters to ten centimeters.

Grade 6 is characterized by a few meters of massive ultramylonites (Fig. 9g). 


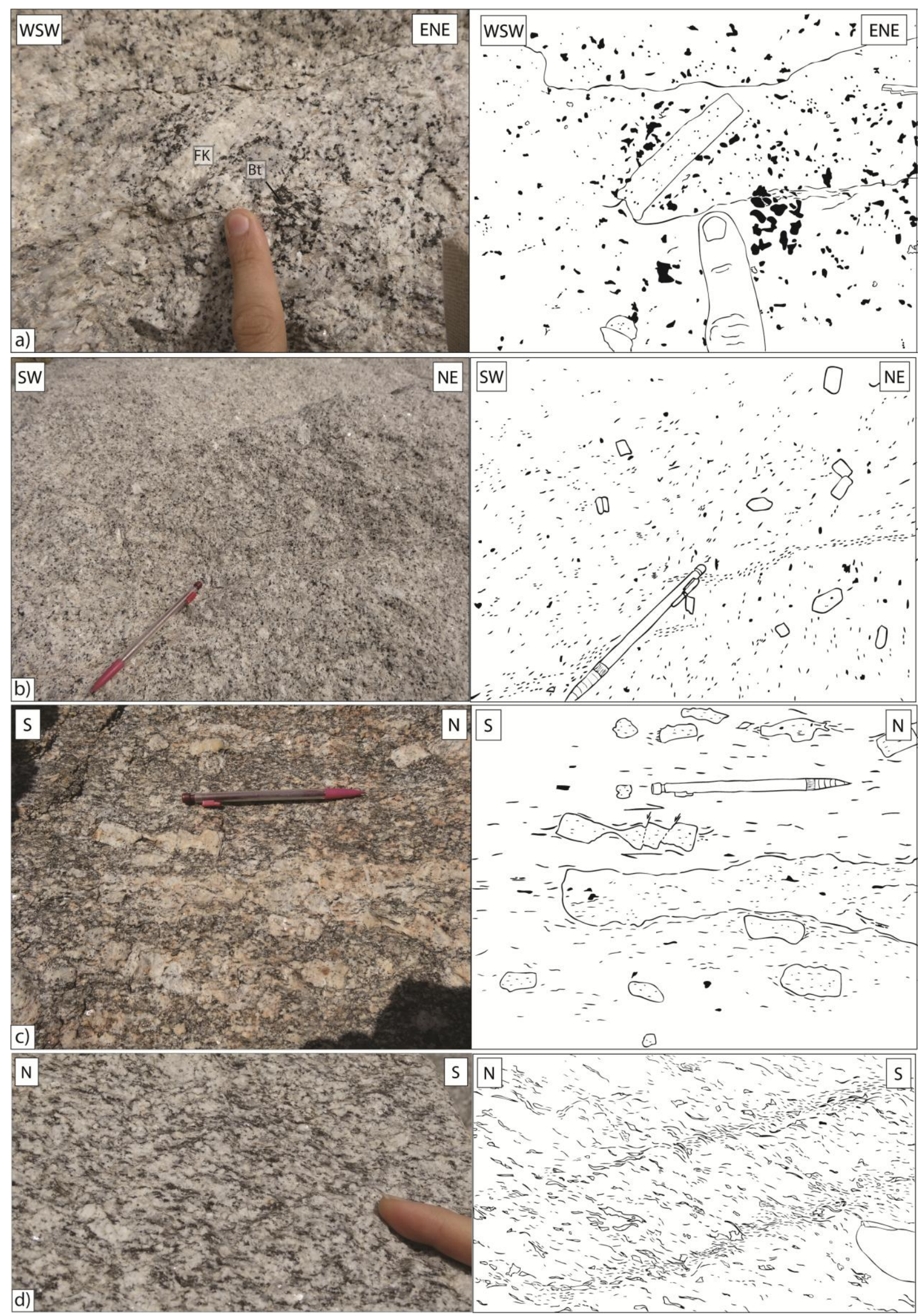



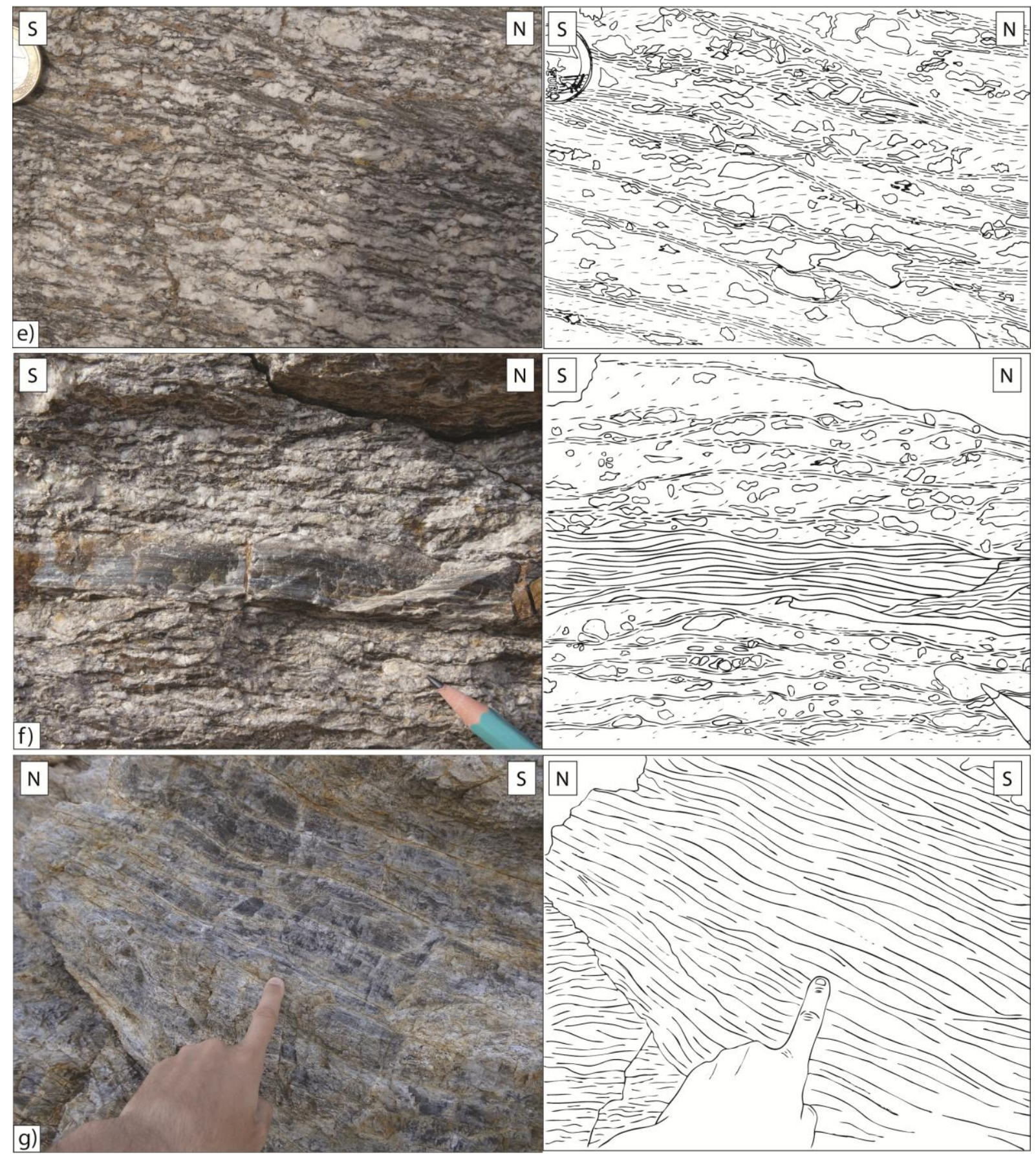

Figure 9: Structural field scale of strain facies. The seven grades of deformation are described in the text.

Field observations across the entire intrusive bodies allow us to propose a qualitative map depicting the distribution of the magmatic and ductile deformation in granites (Fig. 10a). This map shows a gradual increase in the intensity of deformation from south to north, or from base to top. The least deformed rocks (grades 0,1 and 2) are found in the southern part 
of the two granites (Fig. 10a). In contrast, in the northern part, approaching the contact with the Gialiskari sedimentary unit, the two granites are strongly deformed (grades 3, 4, 5 and 6). A strong increase in strain intensity is also locally observed in the southwestern part of the island, near the village of Kalamos (Fig. 10a). A N-S cross-section crossing the strain gradient upward, i.e. toward the most deformed granite (Fig. 10b), shows the attitude of the northdipping shear zone revealed by these observations. All kinematic indicators show a consistent top-to-the north shear sense compatible with the regional variation of the foliation dip that draws a sigmoid at the scale of ca. $10 \mathrm{~km}$ (Fig. 10b). 


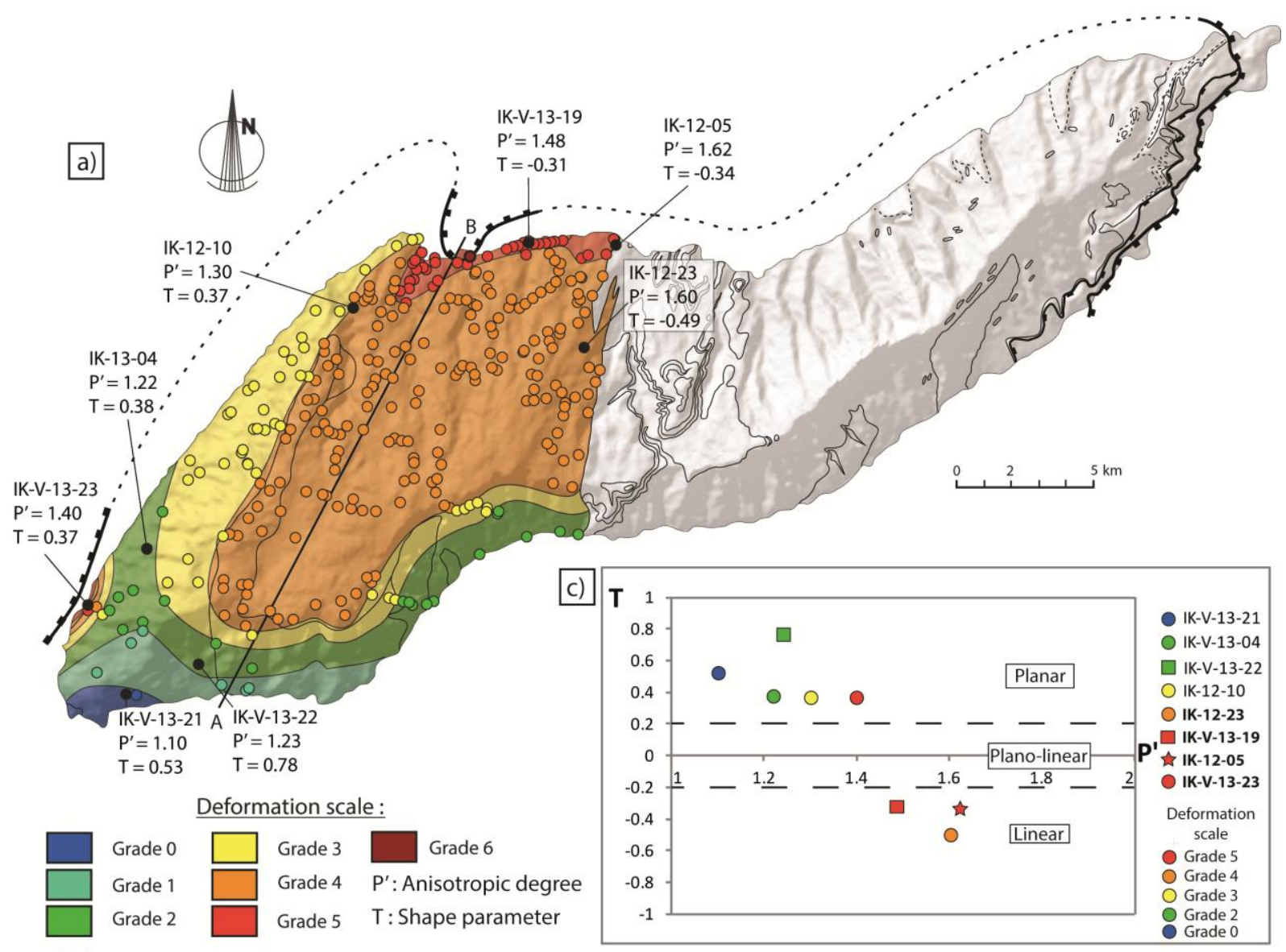

Gialiskari detachment

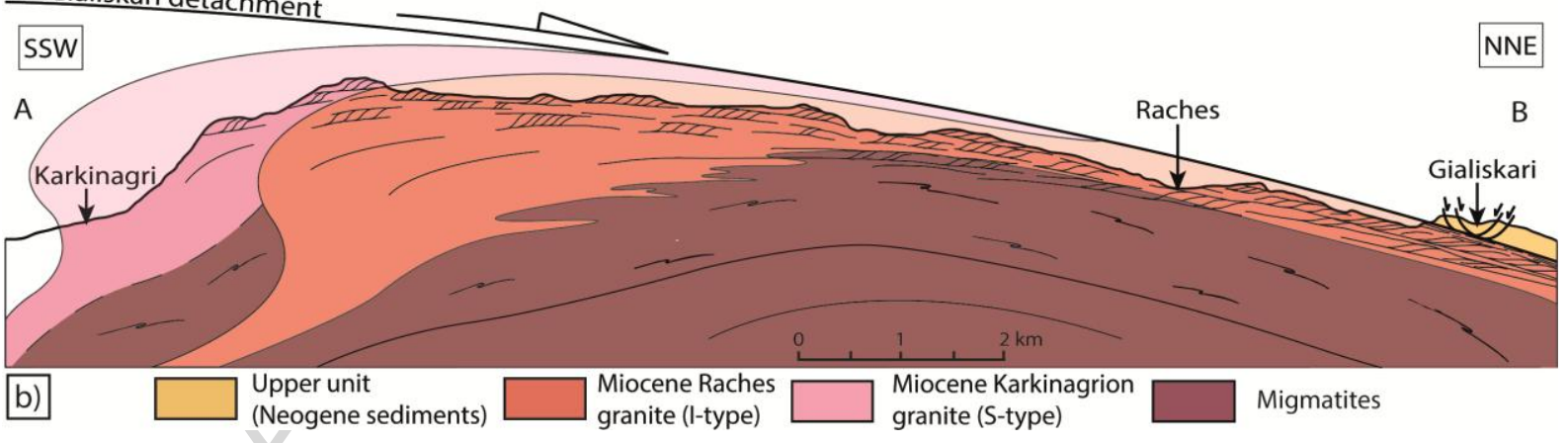

Figure 10: Characterization of a strain gradient in Raches and Karkinagrion intrusions. a) Semiquantitative map of deformation showing the heterogeneous distribution of the ductile deformation in both intrusions. Location of analyzed samples and position of the geological section $A B$ are also represented. b) Geological section AB through the Raches and Karkinagrion intrusions indicating their relative structure (Raches granite intruding the Karkinagrion granite and the migmatites) and their relations with the Gialiskari Detachment (the structurally uppermost parts of intrusions are the most deformed ones). c) Diagram representing the shape parameter $(\mathrm{T})$ vs. the anisotropic degree (P') for samples localized on figure a). 


\subsection{2) Quantification of ductile deformation}

This section documents quantitatively the strain gradient across the deformed granitic bodies by a detailed study of selected outcrops given on Fig. 10a. The Raches granite was targeted because it shows all strain grades. The reconstruction of the strain ellipsoid (following the protocol described in the section 2) allows calculating the degree of anisotropy $\left(\mathrm{P}^{\prime}\right)$ and the shape parameter $(\mathrm{T})$ of biotite fabric for each sample (Borradaile and Werner, 1994; Launeau and Robin, 2005). P' refers to the eccentricity of the 3D fabric ellipsoid and can be correlated with the intensity of biotite preferred orientation. T refers to the symmetry of the 3D fabric ellipsoid. Three cases can be considered: i) if $\mathrm{T}$ is lower than $-0,2$, the lineation is dominant $(\mathrm{L}>\mathrm{S})$ and the ellipsoid is prolate, ii) if $\mathrm{T}$ is comprised between $-0,2$ and 0,2 , the lineation and foliation parameters are close to each other $(\mathrm{L}=\mathrm{S})$ and iii) if $\mathrm{T}$ is comprised between 0,2 and 1, foliation is dominant $(S>L)$ and the ellipsoid is oblate.

The results of the quantitative analysis are shown in the deformation map and the P'-T graph (Fig. 10a and 10c). The $\mathrm{P}^{\prime}=\mathrm{f}(\mathrm{T})$ diagram presents the relationship between the shape parameter and the degree of anisotropy (Fig. 10c). A good correlation is observed between the degree of anisotropy $\left(\mathrm{P}^{\prime}\right)$ and the qualitative strain map elaborated in the field. Indeed, grade 0 corresponds to a very low degree of anisotropy $\left(\mathrm{P}^{\prime}=1.10\right)$, whereas grade 5 has the highest degree of anisotropy $\left(\mathrm{P}^{\prime}=1.62\right)$. The foliation is dominant in the least deformed zones and a gradual evolution is observed toward plano-linear, or even a pure linear fabric, in the most deformed zones. Therefore, the degree of anisotropy and the shape parameter correlates well with strain intensity observed in the field. 


\section{5) The Gialiskari Detachment}

The strain gradient observed when approaching the base of the Gialiskari sedimentary unit (Fig.10a) points to the existence of a shallow north-dipping top-to-the north shear zone. Associated to this shear zone, a clear reorientation from subvertical magmatic foliations to subhorizontal mylonitic foliations has been observed in the field. Furthermore, this shear zone evolves from ductile to brittle through time, the thick cataclasites being the brittle expression of the shear zone continuing motion in the brittle regime. The shear zone brings into close contact the ductilely deformed granites and the non-metamorphosed basin and its normal faults. All these features are characteristic of an exhuming shallow-dipping normal shear zone, hereafter named the Gialiskari Detachment (Fig. 11). The study of this structure together with the map of deformation grades in the granites shows an undulated ductile and then brittle plane, undulation particularly well illustrated by the strain gradient between Armenistis and Gialiskari and the orientation of foliation in this area (Fig. 11). 


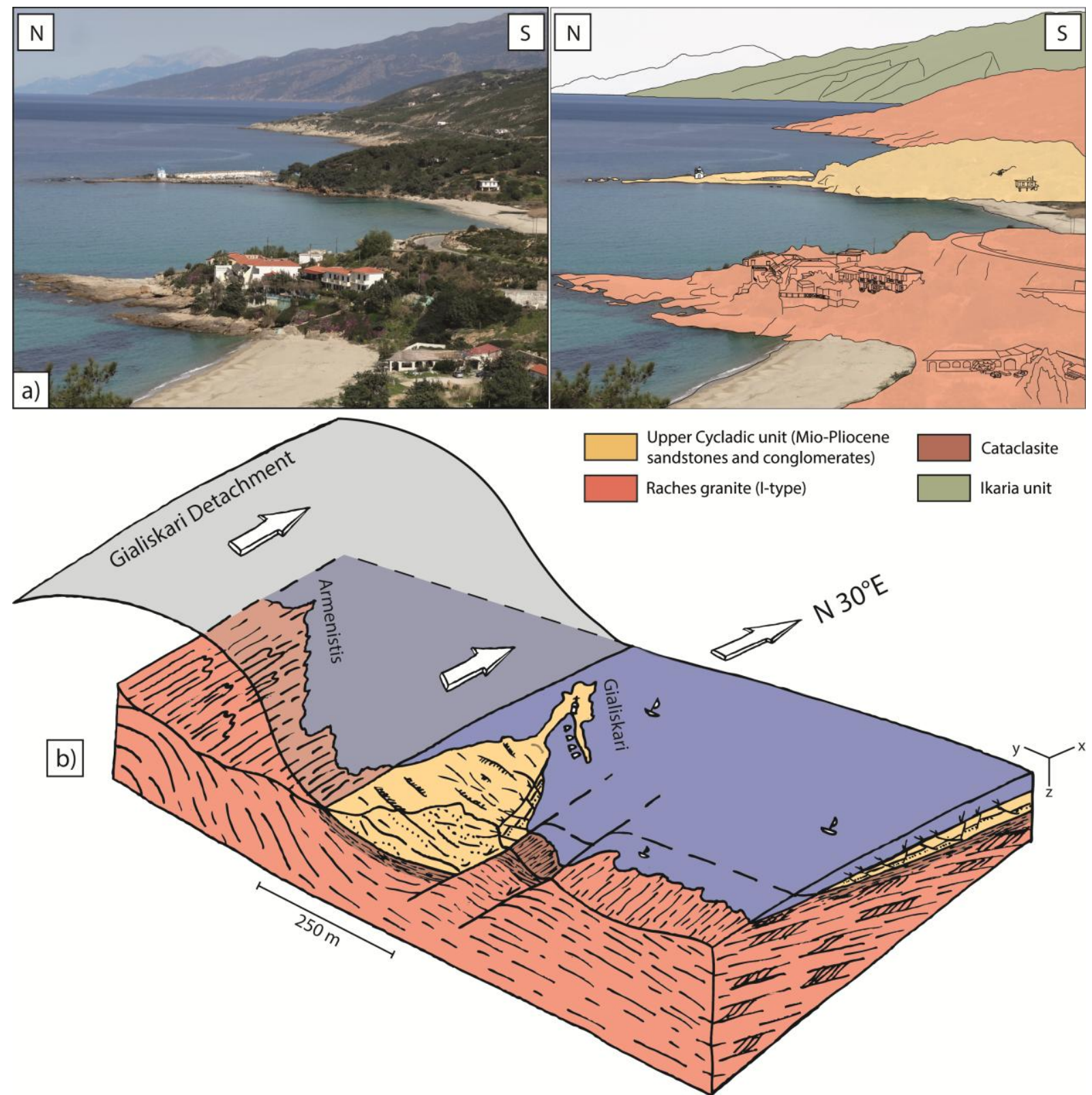

Figure 11: The Gialiskari Detachment structure. a) View of the Gialiskari Detachment near the Gialiskari peninsula, where a non-metamorphic Mio-Pliocene sedimentary unit is superposed on the Raches granite. b) 3D block diagram highlighting the undulated geometry of the Gialiskari Detachment near the Gialiskari peninsula.

In the southwest of the island, near the village of Kalamos, a strong increase in strain intensity is also locally observed with a mylonitic foliation oriented $\mathrm{N} 41^{\circ} \mathrm{E}-33^{\circ} \mathrm{NW}$ and a very well marked stretching lineation oriented $\mathrm{N} 12^{\circ} \mathrm{E}$ (Fig. 12). Ultramylonites are also present, as well as cataclasites. A schematic 3D representation in Fig. 12 shows the relative disposition of structures. The ultramylonites are located at the interface between the Raches 
granite and the lower boundary of a metamorphic rock septa. These ultramylonites form in the landscape a very well defined and continuous surface (Fig. 12a). Approaching the ultramylonites, the granite becomes more deformed with increasingly stretched mineral grains and aggregates (Fig. 12b). There, the seven grades of strain intensity are condensed within a few hundreds of meters (Fig. 10a). S-C shear bands and mica fishes indicate top-to-the north sense of shear (Fig. 12b). The septa consists of highly deformed metasediments including metapelites and marble traversed by granitic dikes carrying also top-to-the north shear sense criteria (Fig. 12 c). A ca. 20 m-thick cataclasites are observed above the septa (Fig. 12a). The general structure of this zone is similar to the one described at Gialiskari, except for the absence of the Mio-Pliocene sedimentary unit that may occur further offshore (Fig. 12d). 

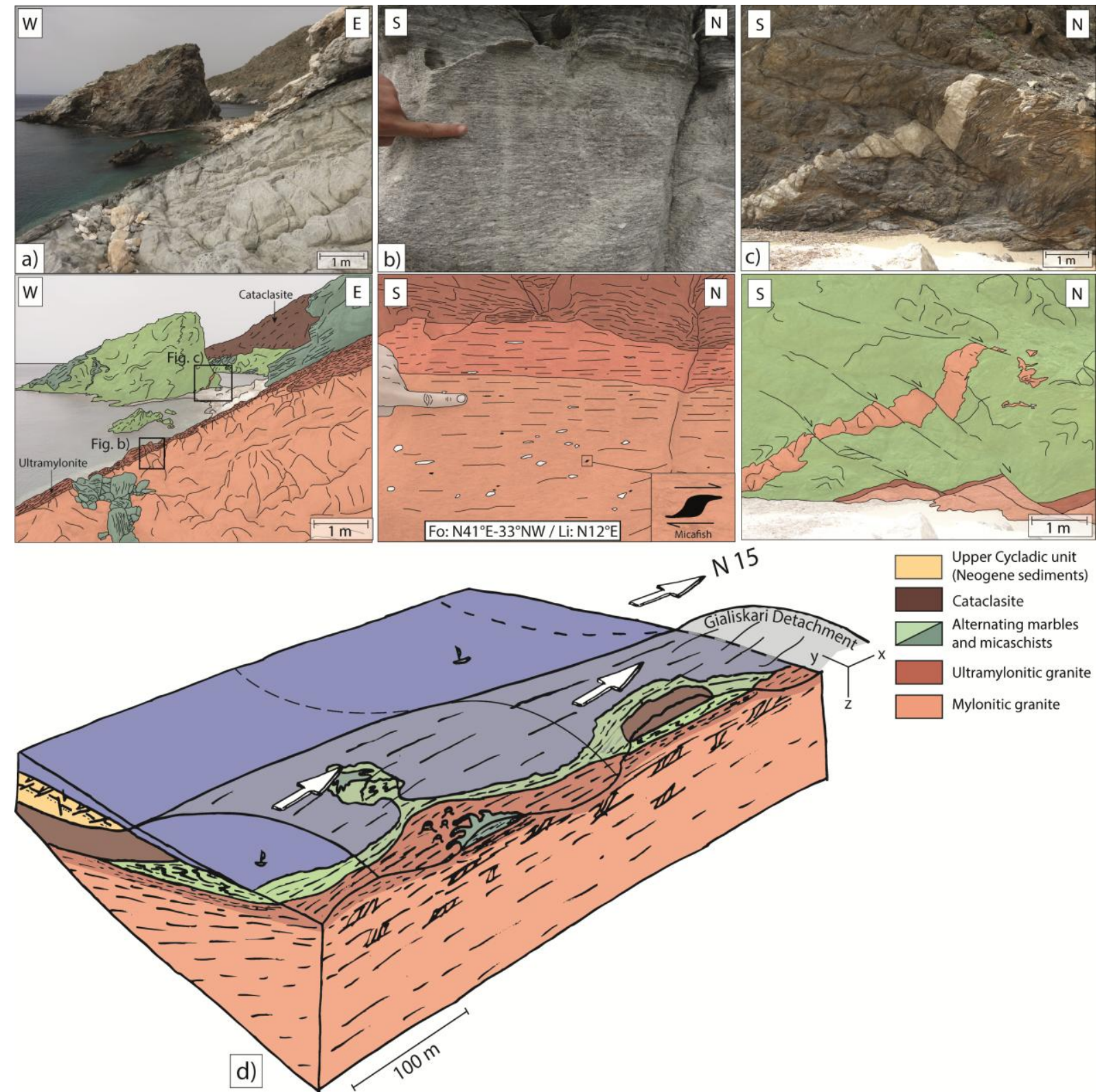

Figure 12: Photographs showing the Gialiskari Detachment structure near the village of Kalamos. a) Base to top view of the mylonitic and ultramylonitic Raches granite, a septa composed by highly deformed metamorphic micaschists and marbles, and on top, a ca. 20 m-thick cataclasite. b) Highly deformed mylonites and ultramylonites in the Raches granite. Mica fish indicates top-to-the north sense of shear. c) Top-to-the north shearing in the metamorphic septa. d) 3D block summarizing the relative position of the structures and their link with the Gialiskari Detachment.

\section{6) Emplacement depth of the Raches granite}

The emplacement depth of an intrusion, i.e. the depth at which the magma crystallizes, is generally not easy to retrieve accurately. Two approaches are generally used. The first approach is based on the petrologic study of metamorphic assemblages that result from the 
metamorphic transformation of adjacent country rocks, and the second one on the intrinsic mineralogy of the intrusion (Nedelec and Bouchez, 2011). The polyphase character of the metamorphic rocks hosting the intrusion hindered the use of the first method (Altherr et al., 1982; Kumerics et al., 2005; Martin et al., 2011). Conversely, the general framework of I-type granitoids enables us to use hornblende chemical composition as a geobarometer. Hammarstrom and Zen (1986) describe the existence of linear relationship between the total number of aluminium atoms (Al Tot) in hornblende and crystallization depth of a pluton. This barometer was defined for conditions similar to those found in the Raches granite. Indeed, it is valid for a classical assemblage of I-type granitoids, including FK, quartz, plagioclase, biotite, hornblende, sphene and Fe-Ti oxides (ilmenite and / or Ti-magnetite).

To test the criticism of Anderson (1996) about the temperature sensibility of this barometer, both cores and rims of amphiboles have been analyzed. No chemical variations were observed between these analyses (Fig. 13a). Our results revealed the presence of two different types of amphibole: ferro-hornblende and magnesio-hornblende (Fig. 13b). Ferrohornblendes crystallize at higher pressure than magnesiohornblende with a crystallization depth of ferro-hornblendes comprised in the range 9-15 km and 5-10 km for magnesio-hornblendes (Fig. 13c). We interpret the crystallization depth of ferro-hornblendes as representing a good estimate of the crystallization depth of the Raches granite. Moreover, the crystallization history of the Raches granite was probably further complicated by the injection of several magmatic pulses as suggested by Altherr et al. (1982), which may explain why magnesio-hornblendes crystallized at shallower depth. The geodynamic consequences of these results are discussed in the following. 

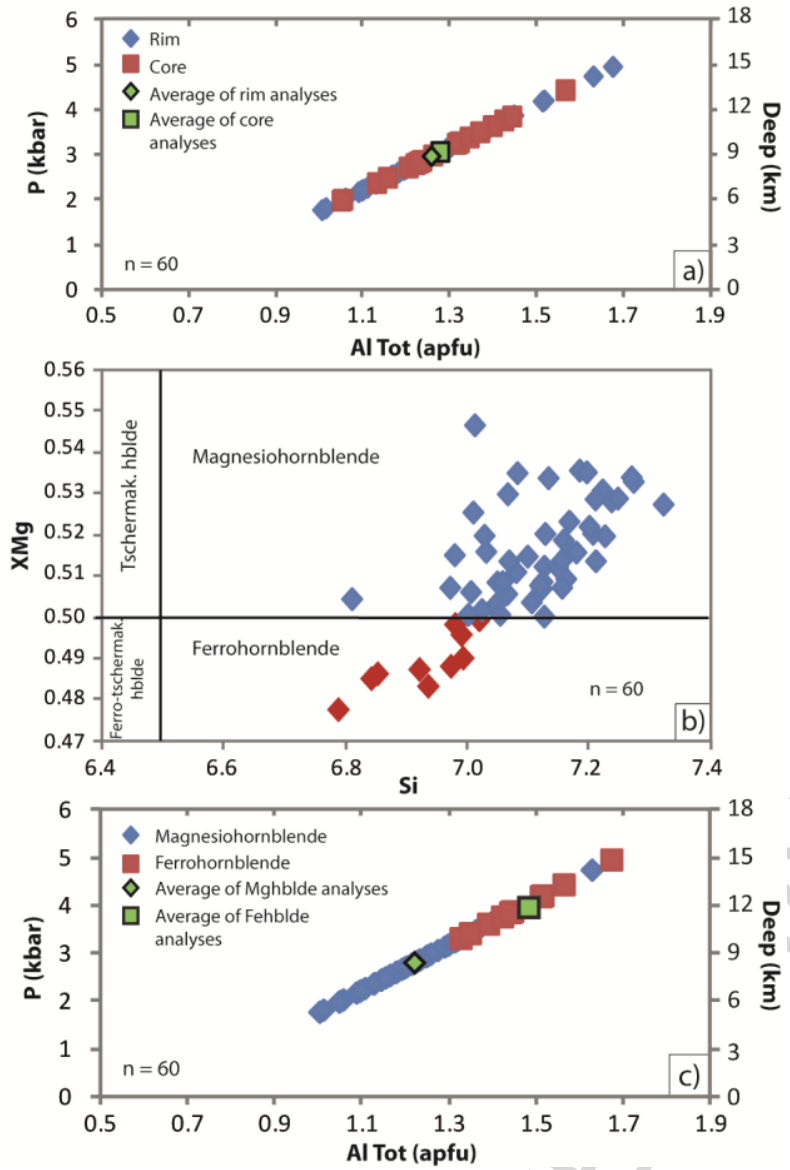

Figure 13: Estimation of emplacement depth of the Raches granite. a) Diagram showing the pressure emplacement of amphibole $v s$ the aluminium atoms number for both core and rim analyses (calibration of Schmidt, 1992). Note that the average of core and rim analyses is similar. b) Chemistry of amphiboles showing the presence of both magnesio- and ferro-hornblende in samples. c) Diagram showing the two different pressure emplacements between the ferro-hornblende (ca. $4 \mathrm{kbar}$ ) and magnesio-hornblende (ca. 3 kbar).

\section{7) Interpretation and discussion}

\section{1) Continuity of deformation in the Raches granite from magmatic to solid state}

The Raches and Karkinagrion granites can be considered asymmetrical laccolithic intrusions (Fig. 10b). The presence of the Karkinagrion granite in the southern part of the island, the top-to-the north sense of shear affecting both granites, as well as the Xylosyrtis granite intruding the southern part of the metamorphic dome, suggest that the magma injection zone was situated in the southern part of the island (Fig. 14). 
The Raches and Karkinagrion granites show evidence for four deformation styles $\left(\mathrm{D}_{1}\right.$ to $\mathrm{D}_{4}$, Figs. 6, 7 and 8). $\mathrm{D}_{1}$ reflects a magmatic deformation related to the early emplacement stage of the intrusion. The first style of deformation is recorded in the least deformed rocks (grades 1 and 2) and is characterized by a planar fabric disposed subvertical stretching lineation oriented N-S (Fig. 14). The map of stretching lineations (Fig. 2) shows a progressive rotation from this $\mathrm{N}-\mathrm{S}$ oriented lineation to the $\mathrm{N} 30^{\circ} \mathrm{E}$ trending one in the northern part of the granite.

The second set of structures $\left(D_{2}\right)$ is characterized by the presence of microfractures in stretched potassic feldspars. According to Bouchez et al (1992), these microfractures are characteristic of the submagmatic state deformation. To form these microfractures, a sufficiently high shear stress has been imposed on the crystal framework of the Raches pluton that remained partially molten. Once formed, these microfractures were instantaneously filled by the magma (Fig. 7). Thereby, the observation of this submagmatic deformation shows that Raches and Karkinagrion plutons are therefore syntectonic intrusions. These microfractures were not observable in the most deformed samples, because the later solid-state deformation overprinted and erased the submagmatic deformation.

$\mathrm{D}_{3}$ deformation features formed once the Raches and Karkinagrion granites had totally crystallized. It is marked by top-to-the northeast ductile shearing deformation, as also observed within the metamorphic dome (Figs. 2 and 14; Beaudoin et al., submitted), suggesting that $D_{3}$ was related to the same regional extension. Strain intensity increases with the approach of the northern contact between the Raches granite and the Gialiskari sedimentary unit and a gradual transition from protomylonitic to mylonitic and also ultramylonitic facies is observed when approaching the Gialiskari Detachment at Gialiskari or at Kalamos (Fig. 14). 
The last event of deformation $\left(\mathrm{D}_{4}\right)$ characterizing the Raches and Karkinagrion granites is brittle, as shown by cataclasites just below the Gialiskari Detachment and normal faults in various places in both granites (Figs. 5, 11 and 12).

The four deformation styles $\left(D_{1}\right.$ to $\left.D_{4}\right)$ observed in the Raches and Karkinagrion granites show an evolution in deformation regime from magmatic to submagmatic, ductile and then brittle deformation. This evolution demonstrates that these granites emplaced during top-to-the north shearing. Although we have described this evolution as a succession of four different sets of small-scale structures, from $\mathrm{D}_{1}$ to $\mathrm{D}_{4}$, these structures simply express a continuum of deformation with progressive strain localization along the main detachment from ductile to brittle conditions.

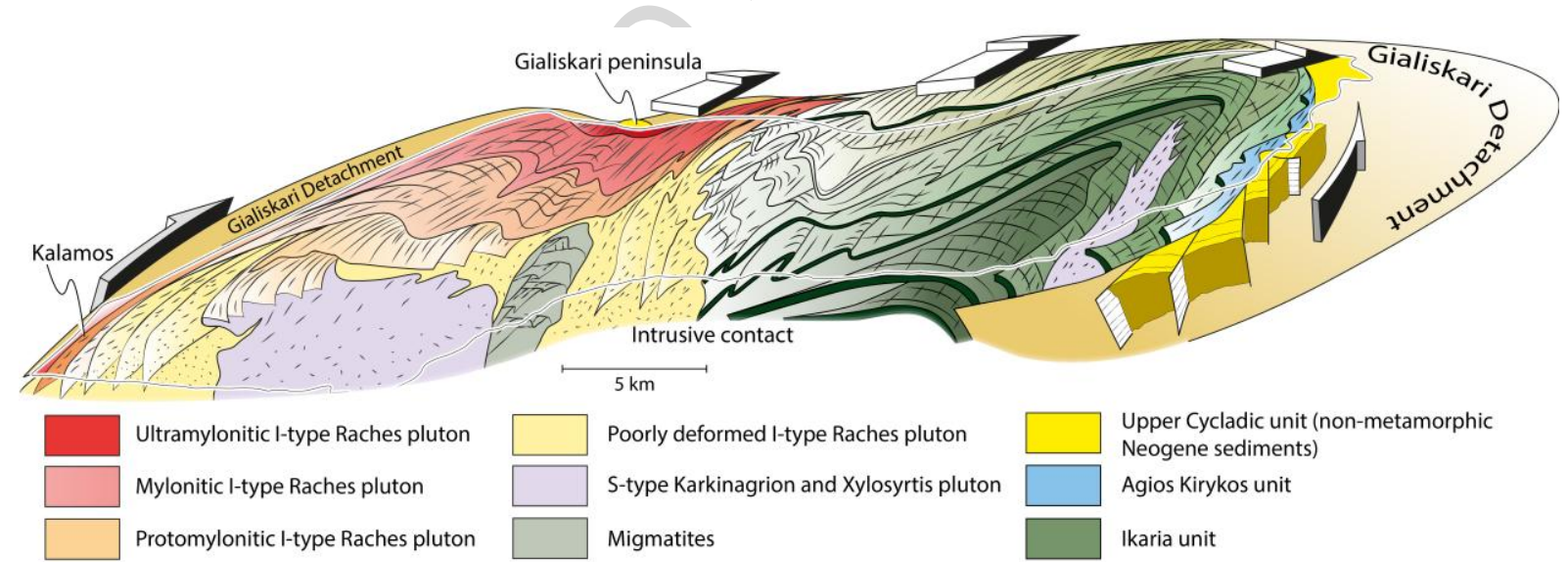

Figure 14: 3D bloc showing the geological architecture of Ikaria Island, integrating and summarizing all the structural information.

\section{2) Localization of deformation during cooling and late-exhumation of the Raches granite}

The Gialiskari Detachment is located along the contact between the Upper Cycladic unit and the Raches granite (Fig. 14). Emplacement, mylonitization and cooling of the Raches and Karkinagrion granites were contemporaneous with top-to-the northeast ductile shear observed along the Gialiskari Detachment. This structure passed over time through the 
ductile-brittle transition during exhumation (Fig. 15). The intrusive contact with the metamorphic dome is parallel to the shearing direction and is strongly folded with fold axes parallel to the same direction. The contact of the pluton with the host rocks has been totally transposed to end parallel to the regional shearing direction in most deformed parts. In agreement with our geobarometry results, this folding is an argument for a deep emplacement of granites in a ductile host rock (Fig. 15: step 1). Indeed, geobarometry results have shown that ferro-hornblende crystallized at high pressure (ca. 3-5 kbar). It thus seems that the geometry of intrusions as a whole, the shape of the intrusive contact and the deformation during the entire cooling period were controlled by the activity of the Gialiskari Detachment.

From the depth of final emplacement, the Raches and Karkinagrion intrusions and the host metamorphic dome were sheared during cooling and a thick ductile shear zone developed below the UC unit. The whole system was then gradually exhumed while deformation progressively localized when approaching the ductile-brittle transition (Fig. 15: step 2). The strain was then accommodated by ultramylonitic and finally cataclastic deformation, still under an extensional regime oriented $\mathrm{N} 30^{\circ} \mathrm{E}$ (Fig. 15: Step 3). 


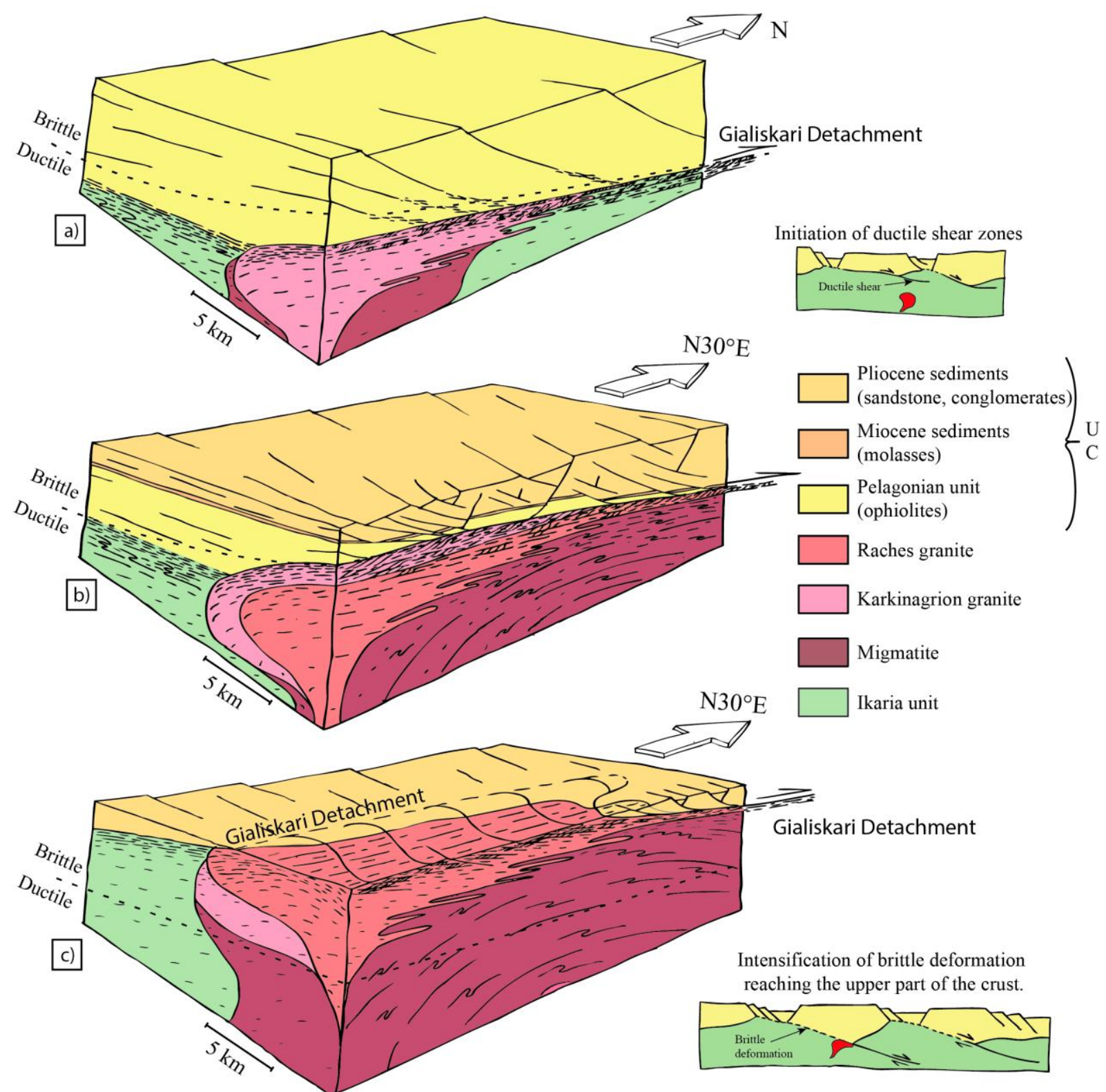

Figure 15: Scenario at intrusions scale showing the evolution of the Gialiskari Detachment system. a) Inception of localization of the ductile deformation within the Gialiskari Detachment located between the Karkinagrion granite related to migmatites and the Upper Cycladic unit (UC). b) Evolution of the deformation through the brittle-ductile transition. Cataclasis is becomes the dominant deformation process when strain localizes in the Gialiskari Detachment. c) Intensive localization of cataclastic deformation in the Gialiskari Detachment overprints previous ductile fabrics. 


\section{3) Granite intrusions and development of metamorphic core complexes in}

\section{the Cyclades}

The Fanari and Gialiskari detachments have similar kinematics except that the Fanari detachment has been later back-tilted during doming (Beaudoin et al., submitted). These two structures, together with the ductile Agios Kyrikos Detachment, make the eastern extension of the North Cycladic Detachment System (NCDS; Fig. 1a; Jolivet et al., 2010) running across Andros, Tinos, Mykonos and then Ikaria. The foliation that formed during top-to-the north shearing deformation below the Agios Kyrikos Detachment was then intruded by the Raches granite, which shows that in the metamorphic units of Ikaria, the activity of the NCDS had started in the metamorphic units of Ikaria before the emplacement of intrusions. The geological evolution of the dome is summarized on a set of reconstructions (Fig. 16). On these reconstructions, the spacing between the main extensional structures is taken from Jolivet et al. (2010). As suggested by Jolivet et al. (2004a) extensional deformation in the Aegean involves a component of boudinaged at all scales, from the outcrop to the crust. Spacing of faults is mainly a consequence of the wavelength of such boudinaged, which itself depends upon crustal thickness.

At 30-35 Ma, acceleration of slab retreat initiated extensional tectonics in the Aegean back-arc domain (Fig. 16; Jolivet and Faccenna, 2000). Crustal thickness before the period of extension (ca. $50 \mathrm{~km}$ ) is taken from Jolivet and Brun (2010) for their geodynamic reconstructions of the Aegean domain. Being a major inherited structure, the base of the UC unit was then reactivated as a large detachment zone, the NCDS (Jolivet et al., 2010). Slab retreat was accompanied by a southward displacement of the volcanic arc, influx of hot asthenosphere and relaxation of HP-LT thermal regime established during subduction (Jolivet et al., 1994; 2013; Jolivet and Brun, 2010). This thermal relaxation involved a temperature 
increase in the lower crust that locally began to melt, forming migmatites (Fig. 16). These migmatites have been described on several Cycladic islands such as Mykonos, Delos, Rhenia, Naxos, Paros (Jansen, 1973; Keay et al., 2001; Vanderhaeghe, 2004; Seward et al., 2009; Denèle et al., 2011) and now Ikaria Island. The upper crust was then heavily fractured and faulted, leading to the formation of crustal-scale high-temperature metamorphic domes inbetween, like the Ikaria MCC. These MCCs are delimited by crustal-scale structures, ductile in the lower crust, brittle in the upper crust (Fig. 16).

The age of the high-temperature event on Ikaria is currently not precisely known. Following up on the comparison with the northern part of the Menderes Massif, a late Oligocene-Early Miocene age can be proposed. Dating of the Simav Detachment, an eastern extension of the NCDS exhuming the northern Menderes Massif, suggests that the activity occurred between 30 and $8 \mathrm{Ma}$ reaching high-temperature conditions before $18 \mathrm{Ma}$ (Bozkurt et al., 2011). This timing would make the Ikaria metamorphic dome coeval in age with the migmatitic dome of Naxos (Altherr et al., 1982; Keay et al., 2001; Duchène et al., 2006). The close association of migmatites with the two-micas Karkinagrion granite with a diffuse contact, and the presence of the S-type Xylosyrtis granite, both dated around 14-13 Ma (Bolhar et al., 2010), reinforces the conclusion that the high-temperature event and crustal partial melting in Ikaria dates back to the Miocene. Moreover, the Raches granite, dated at $13.33 \pm 0.17 \mathrm{Ma}$ by $\mathrm{U} / \mathrm{Pb}$ method on zircon (Bolhar et al., 2010), results from a partial mixing of melted continental felsic crust and mantellic or mafic magma as described by Altherr and Siebel (2002), Pe-Piper et al. (2002). It intrudes the earlier migmatites and the related Karkinagrion granite and also the Ikaria unit at a depth estimated between 10 and $15 \mathrm{~km}$ (Fig. 15: step 1). This emplacement may coincide with the period during which deformation migrated from the Agios Kyrikos Detachment to the Gialiskari Detachment (Fig. 16). 
SSW

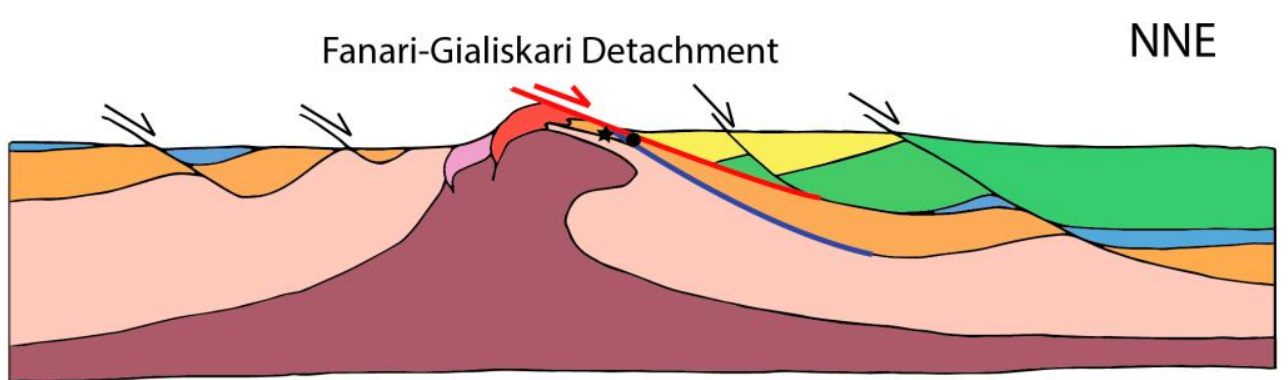

Present

20-10 Ma
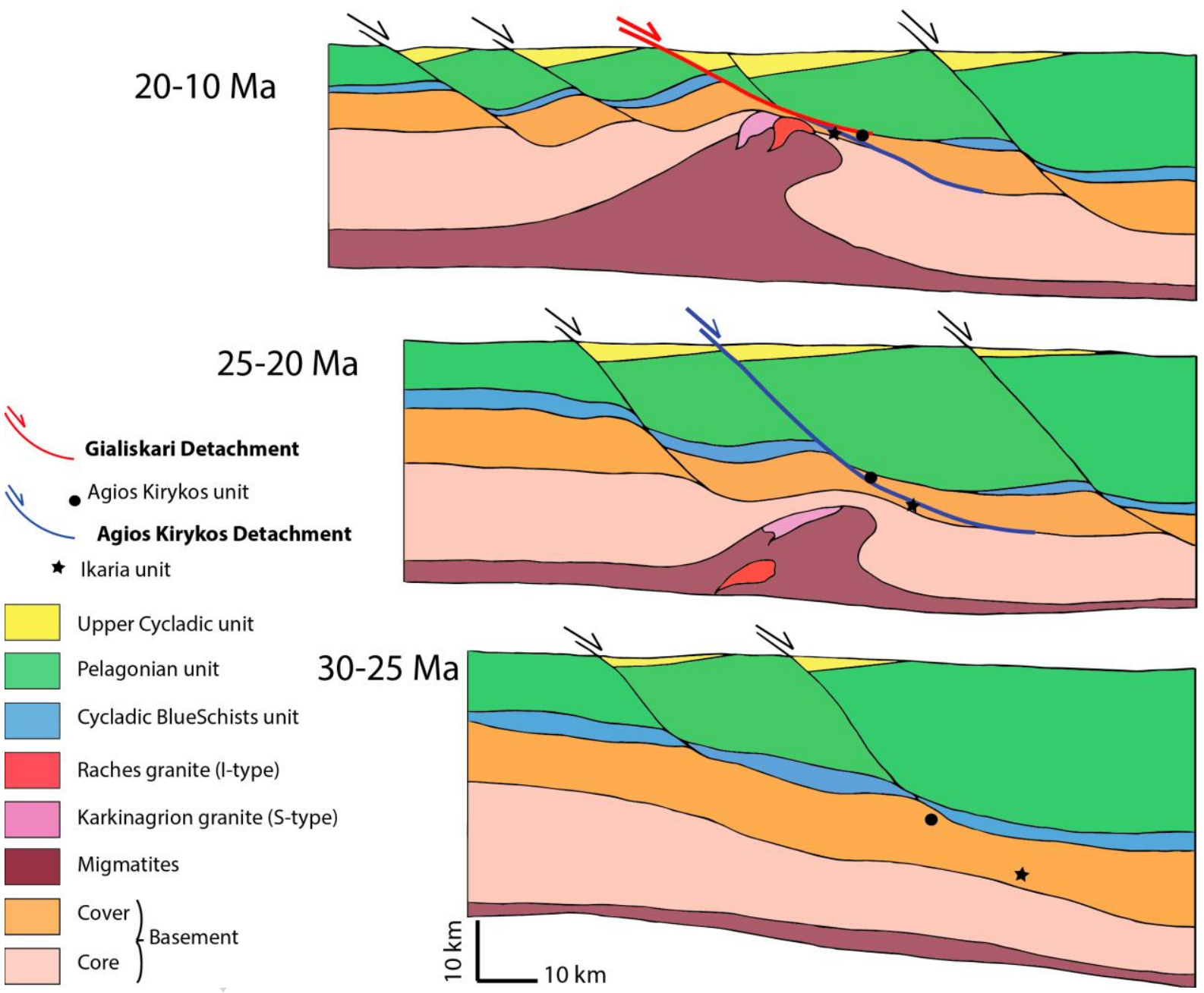

Figure 16: Probable crustal scale scenario of the evolution of structures in Ikaria Island. See text for explanations.

This study provides new data on the debated triggering effect of magmatic intrusions in the development of MCCs. On Ikaria, emplacement of the Raches and Karkinagrion granites postdate the initiation of the MCC exhumation below the Agios Kirykos Detachment. We assume that the pluton had pierced the lower ductile Agios Kirykos Detachment. Contemporaneously, the northeast extensional deformation migrated upward in the crust, along the upper Gialiskari Detachment, where the pluton roof was subsequently sheared by a 
NNE- directed non-coaxial flow from magmatic to solid-state conditions. A similar sequence of events is described on Mykonos, Tinos and Serifos for the NCDS and the WCDS (Denèle et al., 2011; Brichau et al., 2007; Rabillard et al., submitted) as well as on Naxos (Urai et al., 1991; Gautier et al., 1993). On Mykonos, the intrusion postdates the initiation of the Rhenia migmatitic dome (Denèle et al., 2011). On Naxos Island, intrusion of the granodioritic pluton into the roof of the migmatitic dome is dated around $12 \mathrm{Ma}$ (Andriessen et al., 1979; Keay et al., 2001; Wijbrans and McDougall, 1986), while the development of this dome is estimated around 20-21 Ma by U/Pb dating on zircon from migmatitic samples (Keay et al., 2001; Martin et al., 2006). Initiation of top-to-the northeast ductile shear within the greenschist facies dome of Tinos was estimated at $30 \mathrm{Ma}$ (Parra et al., 2002), while this dome and the Tinos Detachment are intruded by the pluton around 14-15 Ma (Avigad and Garfunkel, 1989; Brichau et al., 2007).

These observations show that intrusions emplaced while the MCC was already in an advanced stage of development and thus that the Cycladic plutons did not play a dominant role in the initiation of MCCs, as already proposed by Denèle et al. (2011). It appears that detachments instead controlled the emplacement of granites as described by D'Lemos et al. (1992), Hutton and Reavy (1992), Brown (1994) and Brown and Solar (1998a). It thus seems that major inherited structures allow localizing extensional deformation in the crust during exhumation. The close association of plutons and detachments in the Cyclades then indicates that MCCs are preferential sites for plutons emplacement. Flow of partially molten crust toward the core of the dome induced by crustal-scale boudinage may explain this association (Gautier et al., 1993; Tirel et al., 2004; Huet et al., 2011a, 2011b; Augier et al., 2015).

On the other hand, plutons may help localizing shear zones. When the Raches and Karkinagrion granites intruded the Agios Kirykos Detachment, the motion jumped on a structurally higher position along the Gialiskari Detachment. The same scenario has been 
observed on others Cycladic islands. For examples, when the Tinos granite intruded the Tinos Detachment, the deformation migrated upward along the Livada Detachment (Jolivet and Patriat, 1999; Brichau et al., 2007). Or even, when the Mykonos granite intruded the Livada Detachment the deformation localized on a structurally higher position along the Mykonos Detachment (Lecomte et al., 2010; Denèle et al., 2011). The Meghalo Livadhi detachment cropping out on Serifos Island was also intruded by an I-type granodiorite, itself sheared by the upper Kavos Kiklopas and Aghios Sostis detachments (Rabillard et al., 2015). Upward migration of the actively deformed zone is therefore a consequence of the intrusion that lifts up the ductile-brittle transition (Jolivet and Patriat, 1999; Caggianelli et al., 2014). This is consistent with several models suggesting that crystallizing plutons are capable of producing, at least locally, weak rheological heterogeneities where shear zones can nucleate along the contact with more resistant host rocks (Lister and Baldwin, 1993; Neves et al., 1996; Foster et al., 2001; Aoya et al., 2005; Caggianelli et al., 2014).

\section{8) Conclusion}

This contribution analyses the interrelations between syntectonic intrusions and the development of metamorphic core complexes. An extensive field study of the structure of the Raches and Karkinagrion granites in Ikaria was conducted, resulting in a new geological map that changes drastically from previous works in the area particularly in three key points: i) the Raches granite is an intrusive body within the Ikaria metamorphic dome although the contact appears intensely deformed and locally folded, ii) the Karkinagrion granite can now be considered as an in-situ two-mica granite closely associated with migmatites of the core of Ikaria MCC, iii) the Gialiskari Detachment is a major, regional scale top-to-the north shear 
zone, part of the North Cycladic Detachment System, responsible for exhumation of the Ikaria MCC and the ascent of intrusions in its hanging-wall.

The emplacement of the Karkinagrion and Raches intrusions postdates the initiation of the Ikaria MCC. The exhumation of the metamorphic dome involved the Agios Kirykos Detachment during the first stages, before plutons intruded the detachment and deformation migrated upward. It is concluded that plutons do not nucleate the detachments, but instead detachments localize and control the ascent of plutons.

Acknowledgments: this study is a contribution of the ERC RHEOLITH project (ERC Advanced Grant $n^{\circ}$ 290864) and Labex VOLTAIRE. The authors are indebted to IGME and especially to Nikolas Carras and Adonis Photiades for their help.

\section{References}

Altherr, R., Kreuzer, H., Wendt, I., Lenz, H., Wagner, G.A., Keller, J., Harre, W., Hohndorf, A., 1982. A late Oligocene/early Miocene high temperature belt in the Attic-Cycladic crystalline complex (SE Pelagonian, Greece). Geologisches Jahrbuch E 23, 97-164.

Altherr, R., Siebel, W., 2002. I-type plutonism in a continental back-arc setting: Miocene granitoids and monzonites from the central Aegean Sea, Greece. Contrib Mineral Petrol 143, 397-415. doi:10.1007/s00410-002-0352-y

Andersen, T.B., Jamtveit, B., Dewey, J.F., Swensson, E., 1991. Subduction and eduction of continental crust: major mechanisms during continent-continent collision and orogenic extensional collapse, a model based on the south Norwegian Caledonides. Terra Nova 3, 303310.

Anderson, J.L., 1996. Status of thermobarometry in granitic batholiths. Geological Society of America Special Papers 315, 125-138. doi:10.1130/0-8137-2315-9.125

Andriessen, P.A.M., Boelrijk, N., Hebeda, E.H., Priem, H.N.A., Verdurnen, E.A., Verschure, R.H., 1979. Dating the events of metamorphism and granitic magmatism in the Alpine Orogen of Naxos (Cyclades, Greece). Contributions to Mineralogy and Petrology 69, 215-225.

Aoya, M., Wallis, S.R., Terada, K., Lee, J., Kawakami, T., Wang, Y., Heizler, M., 2005. North-south extension in the Tibetan crust triggered by granite emplacement. Geology 33, 853-856.

Augier, R., Jolivet, L., Gadenne, L., Lahfid, A., Driussi, O., 2015. Exhumation kinematics of the Cycladic Blueschists unit and back-arc extension, insight from the Southern Cyclades (Sikinos and Folegandros Islands, Greece). Tectonics 34, doi:10.1002/2014TC003664.

Avigad, D., Garfunkel, Z., 1989. Low-angle faults above and below a blueschist belt-Tinos Island, Cyclades, Greece. Terra Nova 1, 182-187.

Baldwin, S.L., Lister, G.S., Hill, E., Foster, D.A., McDougall, I., 1993. Thermochronologic constraints on the tectonic evolution of active metamorphic core complexes, D'Entrecasteaux Islands, 
Papua New Guinea. Tectonics 12, 611-628.

Baltatzis, E., Kostopoulos, D., Godelitsas, A., Zachariadis, P., Papanikolaou, D., 2009. Pliocene tourmaline rhyolite dykes from Ikaria Island in the Aegean back-arc region: geodynamic implications. Geodinamica Acta 22, 189-199.

Beaudoin, A., Laurent, V., Augier, R., Rabillard, A., Jolivet, L., Arbaret, L., Menant, A., 2015. Geometry and thermal structure of Ikaria Metamorphic Core Complex (Cyclades, Greece). Implications for Aegean back-arc dynamics. Journal of Geodynamics, submitted.

Blake, M.C., Bonneau, M., Geyssant, J., Kienast, J.R., Lepvrier, C., Maluski, H., Papanikolaou, D., 1981. A geological reconnaissance of the Cycladic blueschist belt, Greece. Geological Society of America Bulletin 92, 247-254.

Bolhar, R., Ring, U., Allen, C.M., 2010. An integrated zircon geochronological and geochemical investigation into the Miocene plutonic evolution of the Cyclades, Aegean Sea, Greece: Part 1: Geochronology. Contributions to Mineralogy and Petrology 160, 719-742.

Bonneau, M., 1984. Correlation of the Hellenide nappes in the south-east Aegean and their tectonic reconstruction. Geological Society, London, Special Publications 17, 517-527.

Bonneau, M., Kienast, J.R., 1982. Subduction, collision et schistes bleus; l'exemple de l'Egée (Grece). Bulletin de la société Géologique de France 7, 785-791.

Boronkay, K., Doutsos, T., 1994. Transpression and transtension within different structural levels in the central Aegean region. Journal of Structural Geology 16, 1555-1573.

Borradaile, G.J., Werner, T., 1994. Magnetic anisotropy of some phyllosilicates. Tectonophysics 235, 223-248.

Bouchez, J.L., Delas, C., Gleizes, G., Nédélec, A., Cuney, M., 1992. Submagmatic microfractures in granites. Geology 20, 35-38.

Bozkurt, E., Satır, M., Buğdaycığlu, Ç., 2011. Surprisingly young Rb/Sr ages from the Simav extensional detachment fault zone, northern Menderes Massif, Turkey. Journal of geodynamics 52, 406-431.

Brichau, S., Ring, U., Carter, A., Monié, P., Bolhar, R., Stockli, D., Brunel, M., 2007. Extensional faulting on Tinos island, Aegean sea, Greece: How many detachments? Tectonics 26. TC4009. doi: 10.1029/2006TC001969

Bröcker, M., Enders, M., 2001. Unusual bulk-rock compositions in eclogite-facies rocks from Syros and Tinos (Cyclades, Greece): implications for $\mathrm{U}-\mathrm{Pb}$ zircon geochronology. Chemical Geology 175, 581-603.

Brown, M., 1994. The generation, segregation, ascent and emplacement of granite magma: the migmatite-to-crustally-derived granite connection in thickened orogens. Earth-Science Reviews 36, 83-130.

Brown, M., Solar, G.S., 1998. Shear-zone systems and melts: feedback relations and self-organization in orogenic belts. Journal of Structural Geology 20, 211-227.

Buick, I.S., 1991. The late Alpine evolution of an extensional shear zone, Naxos, Greece. Journal of the Geological Society 148, 93-103.

Burg, J.-P., Van Den Driessche, J., Brun, J.-P., 1994. Syn-to post-thickening extension: mode and consequences. Comptes rendus de l'Académie des sciences. Série 2. Sciences de la terre et des planètes 319, 1019-1032.

Caggianelli, A., Ranalli, G., Lavecchia, A., Liotta, D., Dini, A., 2014. Post-emplacement thermorheological history of a granite intrusion and surrounding rocks: the Monte Capanne pluton, Elba Island, Italy. Geological Society, London, Special Publications 394, 129-143.

Charles, N., Gumiaux, C., Augier, R., Chen, Y., Zhu, R., Lin, W., 2011. Metamorphic Core Complexes vs. synkinematic plutons in continental extension setting: Insights from key structures (Shandong Province, eastern China). Journal of Asian Earth Sciences 40, 261-278.

Crittenden, M.D., Coney, P.J., Davis, G.H., Davis, G.H., 1980. Cordilleran metamorphic core complexes. Geological Society of America., Mem. 1-490.

D'lemos, R.S., Brown, M., Strachan, R.A., 1992. Granite magma generation, ascent and emplacement within a transpressional orogen. Journal of the Geological Society 149, 487-490.

Davis, G.H., Coney, P.J., 1979. Geologic development of the Cordilleran metamorphic core complexes. Geology 7, 120-124.

Denèle, Y., Lecomte, E., Jolivet, L., Lacombe, O., Labrousse, L., Huet, B., Le Pourhiet, L., 2011. 
Granite intrusion in a metamorphic core complex: the example of the Mykonos laccolith (Cyclades, Greece). Tectonophysics 501, 52-70.

Dewey, J.F., 1988. Extensional collapse of orogens. Tectonics 7, 1123-1139.

Duchene, S., Aissa, R., Vanderhaeghe, O., 2006. Pressure-temperature-time evolution of metamorphic rocks from Naxos (Cyclades, Greece): constraints from thermobarometry and $\mathrm{Rb} / \mathrm{Sr}$ dating. Geodinamica Acta 19, 301-321.

Dürr, S., Altherr, R., Keller, J., Okrusch, M., Seidel, E., 1978. The median Aegean crystalline belt: stratigraphy, structure, metamorphism, magmatism. In: Cloos H, Roeder D, Schmidt K (eds) Alps, Apennines, Hellenides. I.U.G.S. Rep. 38, 455-477.

Faure, M., Bonneau, M., 1988. Données nouvelles sur l'extension néogène de l'Egée: la déformation ductile du granite miocène de Mykonos (Cyclades, Grèce). Comptes rendus de l'Académie des sciences. Série 2, Mécanique, Physique, Chimie, Sciences de l'univers, Sciences de la Terre 307, 1553-1559.

Faure, M., Bonneau, M., Pons, J., 1991. Ductile deformation and syntectonic granite emplacement during the late Miocene extension of the Aegean (Greece). Bulletin de la Societé géologique de France 5, 3-11.

Foster, D.A., Schafer, C., Fanning, C.M., Hyndman, D.W., 2001. Relationships between crustal partial melting, plutonism, orogeny and exhumation: Idaho-Bitterroot batholith. Tectonophysics 342, 313-350.

Fytikas, M., Innocenti, F., Manetti, P., Peccerillo, A., Mazzuoli, R., Villari, L., 1984. Tertiary to Quaternary evolution of volcanism in the Aegean region. Geological Society of London, Special Publications 17, 687-699.

Gapais, D., 1989. Shear structures within deformed granites: mechanical and thermal indicators. Geology 17, 1144-1147.

Gautier, P., Brun, J.-P., Jolivet, L., 1993. Structure and kinematics of upper Cenozoic extensional detachment on Naxos and Paros (Cyclades Islands, Greece). Tectonics 12, 1180-1194.

Gautier, P., Brun, J.P., 1994. Ductile crust exhumation and extensional detachments in the central Aegean (Cyclades and Evvia Islands). Geodinamica Acta 7, 57-85.

Grasemann, B., Petrakakis, K., 2007. Evolution of the Serifos metamorphic core complex. Inside the Aegean Core Complexes. In: G. Lister and M. Foster (Editors), Inside the Aegean Core Complexes. Journal of the Virtual Explorer, Electronic Edition.

Grasemann, B., Schneider, D.A., Stockli, D.F., Iglseder, C., 2012. Miocene bivergent crustal extension in the Aegean: Evidence from the western Cyclades (Greece). Lithosphere L164-1.

Hammarstrom, J.M., Zen, E., 1986. Aluminum in hornblende; an empirical igneous geobarometer. American Mineralogist 71, 1297-1313.

Hill, R.I., Campbell, I.H., Davies, G.F., Griffiths, R.W., 1992. Mantle plumes and continental tectonics. Science 256, 186-193.

Huet, B., Labrousse, L., Jolivet, L., 2009. Thrust or detachment? Exhumation processes in the Aegean: insight from a field study on Ios (Cyclades, Greece). Tectonics 28, TC3007. doi: 10.1029/2008TC002397.

Huet, B., Le Pourhiet, L., Labrousse, L., Burov, E., Jolivet, L., 2011a. Formation of metamorphic core complex in inherited wedges: A thermomechanical modelling study. Earth and Planetary Science Letters 309, 249-257.

Huet, B., Le Pourhiet, L., Labrousse, L., Burov, E., Jolivet, L., 2011b. Post-orogenic extension and metamorphic core complexes in a heterogeneous crust: the role of crustal layering inherited from collision. Application to the Cyclades (Aegean domain). Geophysical Journal International 184, 611-625.

Hutton, D.H.W., Reavy, R.J., 1992. Strike-slip tectonics and granite petrogenesis. Tectonics 11, 960967.

Jansen, J.B.H., 1973. Geological map of Naxos (1/50 000). Nation. Inst. Geol. Mining Res., Athens.

Jolivet, L., Brun, J.-P., 2010. Cenozoic geodynamic evolution of the Aegean. International Journal of Earth Sciences 99, 109-138.

Jolivet, L., Daniel, J.M., Truffert, C., Goffé, B., 1994. Exhumation of deep crustal metamorphic rocks and crustal extension in arc and back-arc regions. Lithos 33, 3-30.

Jolivet, L., Faccenna, C., 2000. Mediterranean extension and the Africa-Eurasia collision. Tectonics 
19, 1095-1106.

Jolivet, L., Faccenna, C., Goffé, B., Burov, E., Agard, P., 2003. Subduction tectonics and exhumation of high-pressure metamorphic rocks in the Mediterranean orogens. American Journal of Science 303, 353-409.

Jolivet, L., Faccenna, C., Huet, B., Labrousse, L., Le Pourhiet, L., Lacombe, O., Lecomte, E., Burov, E., Denèle, Y., Brun, J.-P., others, 2013. Aegean tectonics: Strain localisation, slab tearing and trench retreat. Tectonophysics 597, 1-33.

Jolivet, L., Famin, V., Mehl, C., Parra, T., Aubourg, C., Hébert, R., Philippot, P., others, 2004a. Progressive strain localisation, boudinage and extensional metamorphic complexes, the Aegean Sea Case, in Whitney DL, Teyssier C. and Siddoway CS, Gneiss domes in orogeny: Boulder, Colorado. Geological Society of America Special Paper 380, 185-210.

Jolivet, L., Lecomte, E., Huet, B., Denèle, Y., Lacombe, O., Labrousse, L., Le Pourhiet, L., Mehl, C., 2010. The north cycladic detachment system. Earth and Planetary Science Letters 289, 87104.

Jolivet, L., Menant, A., Sternai, P., Rabillard, A., Arbaret, L., Augier, R., Laurent, V., Beaudoin, A., Grasemann, B., Huet, B., Labrousse, L., Le Pourhiet., L., 2015. The geological signature of a slab tear below the Aegean. Tectonophysics, submitted.

Jolivet, L., Patriat, M., 1999. Ductile extension and the formation of the Aegean Sea. Geological Society, London, Special Publications 156, 427-456.

Jolivet, L., Rimmelé, G., Oberhänsli, R., Goffé, B., Candan, O., 2004b. Correlation of syn-orogenic tectonic and metamorphic events in the Cyclades, the Lycian nappes and the Menderes massif. Geodynamic implications. Bulletin de la Société Géologique de France 175, 217-238.

Keay, S., 1998. The geological evolution of the Cyclades, Greece: constraints from SHRIMP U-Pb geochronology. [Ph.D. thesis]: Canberra, Australian National University, $337 \mathrm{p}$.

Keay, S., Lister, G., Buick, I., 2001. The timing of partial melting, Barrovian metamorphism and granite intrusion in the Naxos metamorphic core complex, Cyclades, Aegean Sea, Greece. Tectonophysics 342, 275-312.

Kokkalas, S., Aydin, A., 2013. Is there a link between faulting and magmatism in the south-central Aegean Sea? Geological Magazine 150, 193-224.

Kumerics, C., Ring, U., Brichau, S., Glodny, J., Monié, P., 2005. The extensional Messaria shear zone and associated brittle detachment faults, Aegean Sea, Greece. Journal of the Geological Society $162,701-721$.

Labrousse, L., Jolivet, L., Agard, P., Hébert, R., Andersen, T.B., 2002. Crustal-scale boudinage and migmatization of gneiss during their exhumation in the UHP province of western Norway. Terra Nova 14, 263-270.

Launeau, P., Archanjo, C.J., Picard, D., Arbaret, L., Robin, P.-Y., 2010. Two-and three-dimensional shape fabric analysis by the intercept method in grey levels. Tectonophysics 492, 230-239.

Launeau, P., Robin, P.-Y.F., 2005. Determination of fabric and strain ellipsoids from measured sectional ellipses implementation and applications. Journal of Structural Geology 27, 22232233.

Le Pichon, X., Angelier, J., 1981. The Aegean Sea. Royal Society of London Philosophical Transactions Series A 300, 357-372.

Lecomte, E., Jolivet, L., Lacombe, O., Denèle, Y., Labrousse, L., Le Pourhiet, L., 2010. Geometry and kinematics of a low-angle normal fault on Mykonos island (Cyclades, Greece): Evidence for slip at shallow dip. Tectonics 29, TC5012, doi:10.1029/2009TC002564.

Lee, J., Lister, G.S., 1992. Late Miocene ductile extension and detachment faulting, Mykonos, Greece. Geology 20, 121-124.

Liati, A., Skarpelis, N., Pe-Piper, G., 2009. Late Miocene magmatic activity in the Attic-Cycladic Belt of the Aegean (Lavrion, SE Attica, Greece): implications for the geodynamic evolution and timing of ore deposition. Geological Magazine 146, 732-742.

Lister, G.S., Baldwin, S.L., 1993. Plutonism and the origin of metamorphic core complexes. Geology 21, 607-610.

Lister, G.S., Banga, G., Feenstra, A., 1984. Metamorphic core complexes of Cordilleran type in the Cyclades, Aegean Sea, Greece. Geology 12, 221-225.

Martin, L., 2004. Signification des âges U-Pb sur zircon dans l'histoire métamorphique de Naxos et 
Ikaria (Cyclades, Grèce). Phd thesis, Université Henri Poincaré, Nancy I, 288 p.

Martin, L., Duchêne, S., Deloule, E., Vanderhaeghe, O., 2006. The isotopic composition of zircon and garnet: a record of the metamorphic history of Naxos, Greece. Lithos 87, 174-192.

Martin, L., Ballevre, M., Boulvais, P., Halfpenny, A., Vanderhaeghe, O., Duchêne, S., Deloule, E., 2011. Garnet re-equilibration by coupled dissolution-reprecipitation: evidence from textural, major element and oxygen isotope zoning of "cloudy" garnet. Journal of Metamorphic Geology 29, 213-231.

Nédélec, A., Bouchez, J.-L., 2011. Pétrologie des granites: structure, cadre écologique. Vuibert.

Neves, S.P., Vauchez, A., Archanjo, C.J., 1996. Shear zone-controlled magma emplacement or magma-assisted nucleation of shear zones? Insights from northeast Brazil. Tectonophysics 262, 349-364.

Papanikolaou, D.J., 1978. Contribution to the geology of Ikaria island, Aegean Sea. Ann Geol Pays Hellen 29, 1-28.

Parra, T., Vidal, O., Jolivet, L., 2002. Relation between the intensity of deformation and retrogression in blueschist metapelites of Tinos Island (Greece) evidenced by chlorite-mica local equilibria. Lithos 63, 41-66.

Pe-Piper, G., Piper, D.J., Matarangas, D., 2002. Regional implications of geochemistry and style of emplacement of Miocene I-type diorite and granite, Delos, Cyclades, Greece. Lithos 60, 47 66.

Pennacchioni, G., 2005. Control of the geometry of precursor brittle structures on the type of ductile shear zone in the Adamello tonalites, Southern Alps (Italy). Journal of Structural Geology 27, $627-644$.

Pennacchioni, G., Zucchi, E., 2013. High temperature fracturing and ductile deformation during cooling of a pluton: The Lake Edison granodiorite (Sierra Nevada batholith, California). Journal of Structural Geology 50, 54-81.

Photiades, A.D., 2002. The ophiolitic molasse unit of Ikaria Island (Greece). Turkish Journal of Earth Sciences 11, 27-38.

Photiades, A., Keay, S., 2003. Geological and geochronological data for Sikinos and Folegandros metamorphic units (Cyclades, Greece): Their tectono-stratigraphic significance. Bull. Geol. Soc. Greece 35, 35-45.

Rabillard, A., Arbaret, L., Jolivet, L., Le Breton, N., Gumiaux, C., Augier, R., and Grasemann, B., 2015. Pluton emplacement along a large-scale detachment system: the example of the Serifos granodiorite (Cyclades archipelago, Greece). Tectonics, accepted with minor modifications.

Ring, U., 2007. The Geology of Ikaria Island: the Messaria extensional shear zone, granites and the exotic Ikaria nappe: Inside the Aegean Metamorphic Core Complexes. In: Gordon Lister MF, Ring U (eds) Journal of the Virtual Explorer, Electronic Edition 27 (paper 3). doi:10.3809/jvirtex.2007.00171.

Ring, U., Glodny, J., Will, T., Thomson, S., 2010. The Hellenic subduction system: high-pressure metamorphism, exhumation, normal faulting, and large-scale extension. Annual Review of Earth and Planetary Sciences 38, 45-76.

Rosenberg, C.L., Handy, M.R., 2005. Experimental deformation of partially melted granite revisited: implications for the continental crust. Journal of Metamorphic Geology 23, 19-28.

Schmidt, M.W., 1992. Amphibole composition in tonalite as a function of pressure: an experimental calibration of the Al-in-hornblende barometer. Contributions to Mineralogy and Petrology 110, 304-310.

Seward, D., Vanderhaeghe, O., Siebenaller, L., Thomson, S., Hibsch, C., Zingg, A., Holzner, P., Ring, U., Duchêne, S., 2009. Cenozoic tectonic evolution of Naxos Island through a multi-faceted approach of fission-track analysis. Geological Society, London, Special Publications 321, 179-196.

Stouraiti, C., Mitropoulos, P., Tarney, J., Barreiro, B., McGrath, A.M., Baltatzis, E., 2010. Geochemistry and petrogenesis of late Miocene granitoids, Cyclades, southern Aegean: Nature of source components. Lithos 114, 337-352.

Tirel, C., Brun, J.-P., Burov, E., 2004. Thermomechanical modeling of extensional gneiss domes. Geological Society of America Special Papers 380, 67-78.

Tomaschek, F., Kennedy, A.K., Villa, I.M., Lagos, M., Ballhaus, C., 2003. Zircons from Syros, 
Cyclades, Greece recrystallization and mobilization of zircon during high-pressure metamorphism. Journal of Petrology 44, 1977-2002.

Trotet, F., Vidal, O., Jolivet, L., 2001. Exhumation of Syros and Sifnos metamorphic rocks (Cyclades, Greece): new constraints on the PT paths. European Journal of Mineralogy 13, 901-902.

Turrillot, P., Faure, M., Martelet, G., Chen, Y., Augier, R., 2011. Pluton-dyke relationships in a Variscan granitic complex from AMS and gravity modelling. Inception of the extensional tectonics in the South Armorican Domain (France). Journal of Structural Geology 33, 16811698.

Urai, J.L., Schuiling, R.D., Jansen, J.B.H., 1991. Alpine deformation on Naxos (Greece). Geological Society of London, Special Publications 54, 509-522.

Vandenberg, L.C., Lister, G.S., 1996. Structural analysis of basement tectonites from the Aegean metamorphic core complex of Ios, Cyclades, Greece. Journal of Structural Geology 18, 14371454.

Vanderhaeghe, O., 2004. Structural development of the Naxos migmatite dome. Geological Society of America Special Papers 380, 211-227.

Vernon, R.H., 2000. Review of microstructural evidence of magmatic and solid-state flow. Visual Geosciences 5, 1-23.

Weidmann, M., Solounias, N., Drake, R.E., Curtis, G.H., 1984. Neogene stratigraphy of the eastern basin, Samos island, Greece. Geobios 17, 477-490.

Wernicke, B., 1981. Low-angle normal faults in the Basin and Range Province: nappe tectonics in an extending orogen. Nature 291, 645-648.

Wijbrans, J.R., McDougall, I., 1986. 40Ar/39Ar dating of white micas from an Alpine high-pressure metamorphic belt on Naxos (Greece): the resetting of the argon isotopic system. Contributions to Mineralogy and Petrology 93, 187-194. 